\title{
REVIEW
}

\section{Obesity and endocrine-disrupting chemicals}

\author{
Angelica Amorim Amato ${ }^{1,2}$, Hailey Brit Wheeler ${ }^{2}$ and Bruce Blumberg 2,3,4 \\ ${ }^{1}$ Department of Pharmaceutical Sciences, University of Brasilia, Brasilia, Brazil \\ ${ }^{2}$ Department of Developmental and Cell Biology, University of California, Irvine, California, USA \\ ${ }^{3}$ Department of Pharmaceutical Sciences, University of California, Irvine, California, USA \\ ${ }^{4}$ Department of Biomedical Engineering, University of California, Irvine, California, USA
}

Correspondence should be addressed to B Blumberg: Blumberg@uci.edu

\begin{abstract}
Obesity is now a worldwide pandemic. The usual explanation given for the prevalence of obesity is that it results from consumption of a calorie dense diet coupled with physical inactivity. However, this model inadequately explains rising obesity in adults and in children over the past few decades, indicating that other factors must be important contributors. An endocrine-disrupting chemical (EDC) is an exogenous chemical, or mixture that interferes with any aspect of hormone action. EDCs have become pervasive in our environment, allowing humans to be exposed daily through ingestion, inhalation, and direct dermal contact. Exposure to EDCs has been causally linked with obesity in model organisms and associated with obesity occurrence in humans. Obesogens promote adipogenesis and obesity, in vivo, by a variety of mechanisms. The environmental obesogen model holds that exposure to obesogens elicits a predisposition to obesity and that such exposures may be an important yet overlooked factor in the obesity pandemic. Effects produced by EDCs and obesogen exposure may be passed to subsequent, unexposed generations. This "generational toxicology" is not currently factored into risk assessment by regulators but may be another important factor in the obesity pandemic as well as in the worldwide increases in the incidence of noncommunicable diseases that plague populations everywhere. This review addresses the current evidence on how obesogens affect body mass, discusses long-known chemicals that have been more recently identified as obesogens, and how the accumulated knowledge can help identify EDCs hazards.
\end{abstract}

\author{
Key Words \\ - obesogen \\ - endocrine-disrupting \\ chemical \\ - EDC \\ - transgenerational \\ - adipogenesis \\ > obesity
}

\section{Introduction}

The incidence of obesity around the world has tripled since the 1970s, affecting more than 650 million people (1). Within the United States alone, 39.8\% of adults (93.3 million) aged 20 and over, along with $18.5 \%$ (41 million) of youth aged $2-19$ are classified as obese $(2,3,4)$. Imbalance between caloric intake and energy expenditure has always been the major explanation given for weight gain and obesity. If the uptake in caloric dense food is greater than the energy expenditure, it is expected that the accumulation of fat will increase in direct proportion to this imbalance. However, different lines of evidence challenge the energy balance model as a full explanation for weight gain. For example, the nature of calories consumed seems to be more important than the total number of calories. Recent studies reported that the glycemic load of carbohydrate calories consumed (high vs low glycemic load) was a more important predictor of weight gain than was the total number of calories from carbohydrate $(5,6)$. With respect to caloric intake, NHANES data demonstrated that US adults are largely following the dietary guidelines distributed by the American Heart Association, the US Department of Agriculture and Health and Human Services for the last 40 years $(7,8)$. From 1965 to 2011, average dietary fat consumption decreased from 45 to $34 \%$ in US adults, with carbohydrate consumption increasing from 39 to $51 \%$. Despite these recommended (c) 2021 The authors Published by Bioscientifica Ltd
This work is licensed under a Creative Commons Attribution-NonCommercial-NoDerivatives 4.0 Internationab sicense.ifica . com at $04 / 26 / 2023$ 10:46:40AM 
dietary shifts, the average BMI for men and women has increased from to $29 \mathrm{~kg} / \mathrm{m}^{2}$ over this same time period $(8,9)$.

Rather than physical activity decreasing, a study analyzing data from the US National Health and Nutrition Examination Study (NHANES) between 1988 and 2006 reported that leisure time physical activity has increased by $47 \%$ in males and $120 \%$ in females over this time period (10). This study additionally showed that that for an equivalent amount of caloric consumption and physical activity, adults in 2006 had a BMI $2.3 \mathrm{~kg} / \mathrm{m}^{2}$ higher than did adults in 1988 (10). However, the impact of changes in physical activity pattern trends over the last decades in the obesity epidemics is not straightforward. In parallel with the increase in leisure physical activity, a decrease in occupational physical activity has been reported (11).

Genetics is widely believed to be associated with obesity, and around 40-70\% of inter-individual BMI variability is considered heritable $(12,13)$. Genome-wide association studies have revealed that BMI is affected by many loci, each with small effect sizes (14). However, the known gene variants can only explain $2.7 \%$ of the individual variation in BMI (15). Despite the significance of genetic factors for weight gain, the two most commonly given explanations for the substantial increases in obesity incidence observed worldwide - genetics and energy balance - cannot fully explain it.

Several environmental factors are known to impact obesity susceptibility (reviewed in 16, 17). These include stress (18), disrupted circadian rhythms (19), the composition of the gut microbiome (bacterial diversity, balance of bacterial types and the particular species found) $(20,21)$, air pollution from proximity to highways (22), disrupted circadian rhythms and time and frequency of eating (23) to name a few. Notably, the sensitivity to such environmental stressors is enhanced during critical windows of development, and exposure within these periods may lead to increased obesity risk later in life (16).

On a physiopathological basis, obesity is defined as an abnormal or excessive accumulation of adipose tissue that presents a health risk (24). It has long been acknowledged that fat distribution rather than its total amount is more closely linked to obesity-related morbidity and mortality. White adipose tissue (WAT) surrounding abdominal viscera in the mesentery and omentum, known as visceral WAT, poses a greater health risk than WAT in S.C. areas, known as S.C. WAT (25). Visceral and S.C. WAT differ in functional features, such as regulation of triglyceride storage and release, and production of adipokines (26). Moreover, WAT is a sexually dimorphic endocrine organ.
Men tend to have more visceral fat whereas women have more S.C. fat stores. Visceral fat is associated with a higher risk of diabetes largely due to the production of proinflammatory cytokines, which contribute to insulin resistance. In contrast, S.C. fat protects against impaired glucose metabolism and lessens the risk of heart disease, hypertension, stroke, and diabetes in women (27). The number of adipocytes is determined mostly from prenatal life through adolescence $(28,29)$. However, there is increasing evidence that expansion of WAT mass occurring during the development of obesity in adulthood results both from increased white adipocyte size (hypertrophy) and from an increase in adipocyte number (hyperplasia) (30). Moreover, the manner through which WAT expands in response to positive energy balance is most likely dependent upon the depot location $(31,32)$ and gender (33).

Obesity is a risk factor for other diseases including type 2 diabetes, cardiovascular disease, cancers, hypertension, and asthma (reviewed in 17). In addition, obese individuals have a higher prevalence of mental illnesses including depression, eating disorders, anxiety, and low self-esteem $(34,35)$. The rising incidence of obesity and its associated comorbidities have greatly increased national health care costs. In 2008, an estimated \$147 billion US dollars was spent to cover the average medical cost of obesity within the US. Since then, national health care costs have risen to $\$ 208$ billion annually (36). More directly, medical costs for obese individuals are \$1429 higher than those of healthy weight, costing around $\$ 3508$ per obese adult (37).

\section{Beyond the usual explanations for obesity}

In addition to energy balance, weight gain can be influenced by a variety of complex 'environmental factors' (broadly defined). These can include socio-economic status, family lifestyle, workplace culture, and urban design (the 'built environment'). Coupled with inadequate physical activity and nutritional imbalance, these may explain some of the obesity pandemic (35). However, it is hard to argue that these alone are the main contributors to obesity. The prevalence of obesity is increasing in children as well as in adults. The percentage of obese children aged 2-5 years has doubled from 5 to $13.9 \%$ and quadrupled in ages 12-19 from 5 to $20.6 \%$ (3). Currently, there are an estimated 107.7 million children worldwide under the age of 20 that are considered obese, including those under the age of 2 (1). Unless the average infant consumes more calories and

This work is licensed under a Creative Commons Attribution-NonCommercial-NoDerivatives 4.0 International License.ifica, com at $04 / 26 / 2023 \quad 10: 46: 40 \mathrm{Am}$ 
exercises less than previous generations, it may have been born with more fat due to an alteration in the prenatal or early postnatal environment. In addition, animals that reside within human-influenced environments (pets, laboratory animals, and feral rats in cities) have also exhibited increases in obesity over the past decades. This includes animals maintained in research colonies where food intake is regulated (38). A reasonable inference is that something has changed within the environment in which humans and animals reside, independent of overeating and sedentary lifestyle of obesity.

\section{The intrauterine environment and predisposition to obesity}

Environmental stressors experienced during fetal development can have profound effects later in life. For example, mothers that were in their first and second trimester of pregnancy during the Dutch Hunger Winter of 1944-1945 gave birth to children that were predisposed to obesity later in life compared with the children of mothers who had not experienced famine during pregnancy (39). Maternal smoking during pregnancy is a much studied and well-established risk factor for obesity in the exposed offspring (reviewed in 40).

Fetal experience within the intrauterine environment has the potential to increase the risk of disease via alterations in metabolic programming, hormonal control, and gene regulation (41). Not only poor prenatal nutrition but also maternal obesity (presumably reflecting excess prenatal nutrition) can lead to life-long health consequences, including obesity (42). This phenomenon was first referred to as 'fetal programming' by David Barker who suggested that there were associations between changes in the intrauterine environment and adverse health outcomes in adults. Ultimately, prenatal programming led to the development of Barker's 'thrifty phenotype hypothesis' (43), which proposed that malnutrition, in utero, programed the fetus to use calories sparingly later in life. If the postnatal environment is calorie-rich, this mismatch between the thrifty phenotype and abundant calories leads to adverse outcomes such as obesity.

The 'Developmental Origins of Health and Disease' (DOHaD) model was proposed to account for the observation that developmental programming continues throughout early life, rather than simply during gestation and that this programming is critical for the establishment of adult physiology $(44,45,46)$. The DOHaD hypothesis holds that exposure to poor nutrition, stress, hormonal shifts and other disruptions during early life can lead to long-term physiological adaptations that can permanently influence health and disease susceptibility $(42,44,45)$. All of these stressors can modify the neuroendocrine programming that regulates growth, fuel homeostasis, appetite, and adipocyte differentiation, leading to increased risk of obesity $(47,48,49,50)$. Also, it has become quite clear that chemical exposures are another important factor in $\mathrm{DOHaD}$ (17).

\section{Endocrine-disrupting chemicals}

The endocrine system ultimately modulates function in tissues that regulate weight and metabolism. Endocrine hormones such as insulin, thyroid hormone, estrogens, and androgens are well known to regulate pathways that control the number and size of adipocytes and a variety of peptide hormones regulate appetite and satiety. These have been reviewed in great detail elsewhere (e.g. 17). The Endocrine Society defined an endocrine-disrupting chemical (EDC) as an exogenous chemical, or mixture that interferes with any aspect of hormone action (51). This differs somewhat from the toxicological definition of an EDC which adds the additional requirement that exposure must cause adverse effects in an intact organism. To an endocrinologist, disruption of endocrine function is adverse; per se. The key characteristics of EDCs have been defined in order to facilitate hazard identification (52). EDCs have become pervasive contaminants in our environment and human exposure can result from agrochemicals, food, pharmaceutical drugs, personal care products, medical equipment and even children's toys $(53,54,55)$. The presence of EDCs in commonly used products ensures that humans will be exposed on a daily basis via ingestion, inhalation, or direct dermal contact $(54,56)$. Epidemiological studies have established links between exposure to EDCs and detrimental effects on the endocrine system, leading to neural, metabolic, and fertility defects (54). EDCs can act through a diverse array of hormonal signaling mechanisms to influence physiology $(55,57)$.

Nuclear hormone receptors were the original 'targets' defined for endocrine disruptors. These receptors comprise a superfamily of ligand-regulated transcription factors sharing a modular domain structure consisting of a variable N-terminal A/B domain, a conserved DNAbinding domain, a hinge region, and a C-terminal ligand-binding domain harboring a hydrophobic ligandbinding pocket that can accommodate a variety of 
small lipophilic endogenous and exogenous molecules (58). There are 48 genes that encode nuclear hormone receptors in the human genome, and the ligands regulating the transcription activity of many receptors have been identified (59). Therefore, it should be selfevident that many of these ligand-modulated hormonal signaling pathways will also be susceptible to interference from EDCs.

Among these are key players in development and physiology such as the glucocorticoid receptor (GR), progesterone receptor (PR), retinoic acid receptors $(\mathrm{RAR} \alpha, \beta, \gamma)$, the 9 -cis retinoic acid receptor $(\operatorname{RXR} \alpha, \beta, \gamma)$, the peroxisome proliferator activated receptors (PPAR $\alpha, \beta / \delta$, $\gamma$ ) and the liver ' $\mathrm{X}$ ' receptor $(\mathrm{LXR} \alpha, \beta)$. In principle there is no reason to exclude the possibility that most, if not all members of the nuclear receptor superfamily can be EDC targets, in addition to other ligand-mediated transcription factors such as the aryl hydrocarbon receptor (60). It is also possible that EDCs could disrupt any of the thousands of cellular signaling pathways that are modulated by peptides or small molecules. The emerging concept of 'signal toxicity' opens the possibility that there may be hundreds to thousands of pathways targeted by EDCs (61). In agreement with this concept, the so-called EATs paradigm that defined EDCs as chemicals that disrupted estrogen, androgen or thyroid hormone signaling (62) is currently considered inadequate. Therefore, it is being increasingly discussed that screening approaches for EDCs should include a wider range of cellular signaling pathways. This has been extensively reviewed elsewhere (52) and is beyond the scope of this review.

\section{Endocrine-disrupting chemicals as obesogens}

The term 'obesogen' was coined to describe chemicals (including EDCs) that can promote obesity in humans and animals. Multiple studies have causally linked exposure to EDCs and obesity development in model organisms, either independently or by increasing susceptibility to other factors such as high-fat diet. In humans, data from observational studies indicate that many EDCs known for their obesogenic effect in animals are associated with increased obesity prevalence (63). However, the association between specific EDCs and body weight in humans should be interpreted with caution since there is simultaneous exposure to a broad range of EDCs, in addition to other environmental factors that increase obesity risk.
Obesogens can act directly on adipocytes to increase their number, promote fat storage in existing adipocytes, or produce dysfunctional adipocytes. Obesogens can also indirectly increase adiposity by multiple mechanisms, such as disruption of metabolism and appetite control (reviewed in 16, 17, 64), alteration of metabolic setpoints, induction of unfavorable changes in microbiome composition, and increasing the fraction of caloric intake that is stored as fat (reviewed in 16).

Sensitivity to the obesogenic effects of EDCs is particularly high when exposure occurs within critical developmental windows. This is because the fetus and infant have unique features that lead to higher tissue exposure than adults, such as lower expression of cytochrome P450 enzymes that metabolize xenobiotics (65). Moreover, early life is a developmentally plastic stage in which a wide range of processes are programmed by hormone signaling pathways (63) and can respond and adapt to physiological challenges. This ability also enhances the susceptibility to environmental stressors such as EDCs, which may lead to long-term alterations in various systems, ultimately resulting in increased obesity risk later in life. Indeed, early-life exposure to obesogens may reprogram physiological processes that are critical determinants of body mass, including energy metabolism, appetite control, and adipogenesis, leading to a thrifty phenotype and increasing the susceptibility to weight gain.

The obesogenic effect of early-life exposure to EDCs is supported by many animal and epidemiological studies. Rodent studies reported that perinatal or early postnatal exposure to BPA (66), pesticides (67), nonylphenol (68), and PFOA (69) lead to increased weight gain during adulthood, in dose- and gender-dependent manner. Human studies have also indicated the association between perinatal exposure to EDCs and increased risk of obesity later in life (63). It is important to point out that animal model studies indicate that some EDCs also have obesogenic effects when exposure occurs after critical development periods (67). Therefore, in a scenario of continued exposure, it is most likely that the effects of early life and adulthood exposure ultimately determine the actions of obesogens on phenotype. However, little is known about the interaction of exposure in different time periods.

Early life obesogen exposure can increase white adipose tissue mass by increasing the steady state level of adipocytes, or adipocyte precursors and promotes differentiation of adipocytes from multipotent mesenchymal stromal stem cells (a.k.a., mesenchymal stem cells, MSCs) or existing preadipocytes. Activation of specific nuclear hormone 
receptors by EDCs has been extensively studied as a mechanism underlying obesogen action, since it has the potential to alter fat cell commitment, differentiation and function. The nuclear receptor, PPAR $\gamma$ is the co-called 'master regulator' of adipogenesis (70) and, therefore, is a logical candidate to mechanistically explain the obesogen action of chemicals. Like other PPARs, PPAR $\gamma$ requires heterodimerization with RXR to bind DNA and regulate its target genes. Activation of this heterodimer by endogenous ligands, pharmaceutical drugs or EDCs promotes expression of adipogenic genes that lead to fat cell differentiation. PPAR $\gamma$ engages in a mutually interactive feedback loop with the transcription factors, CCAAT-enhancer binding proteins $(\mathrm{C} / \mathrm{EBP}) \alpha, \quad \beta$, and $\gamma$, that stabilizes and promotes the adipogenic fate (reviewed in 71). Considering this, many screening efforts to identify potential obesogens targeted PPAR $\gamma(72,73$, 74). A variety of actual and potential chemical obesogens have been identified using such screening approaches as adipogenesis inducers in human cell-culture models by activating PPAR $\gamma$, including lactofen, diclofopmethyl, and MEHP (75). However, it is acknowledged that EDCs may induce adipocyte differentiation by PPAR $\gamma$-independent mechanisms. This is the case for bisphenol A, nicotine, organophosphate pesticides, and polychlorinated biphenyls (PCBs), all of which promoted adipogenesis through mechanisms that may not involve direct activation of PPAR $\gamma(71,76)$. PCB-77 acts through the aryl hydrocarbon receptor to promote adipocyte differentiation in 3T3-L1 preadipocytes (60).

Importantly, some effects of obesogens seem to be independent from direct modulation of nuclear hormone receptors. These include the transmission of the obese phenotype to subsequent generations not directly exposed to the chemical, following early life exposure, or the so-called transgenerational effect of obesogens. This has been reported for some chemicals, and there has been a great effort to understand the mechanisms underlying these transgenerational effects; possible candidates are epigenetic modifications and changes in chromatin organization.

\section{Tributyltin the model obesogen}

Tributyltin (TBT) was among the first obesogens to be identified and is currently the most thoroughly studied. TBT binds to and activates PPAR $\gamma$ and RXR (77, $78,79)$ to promote adipocyte commitment (80) and differentiation $(81,82)$. In vitro studies confirmed that
TBT exposure drove the differentiation of murine 3T3-L1 adipocytes into adipocytes via the activation of PPAR $\gamma$ and RXR $(77,78,81,82)$. In addition, 3T3-L1 preadipocytes exposed to TBT produced dysfunctional adipocytes with altered gene expression and lipid metabolism (83). Mouse MSCs differentiated in the presence of TBT or an RXRselective chemical also produced dysfunctional adipocytes with impaired insulin sensitivity, an unfavorable adipokine profile, pro-inflammatory and pro-fibrotic gene expression and impaired thermogenic activity (80).

In vivo studies found that TBT exposure increased fat accumulation and hepatic steatosis in rodents $(77,84,85$, $86)$, fish $(87,88,89,90,91,92)$ and even in snails (93) and Daphnia (94). F0 mice exposed to TBT during pregnancy produced F1 offspring with increased adipose depot size in mice (77) and resulted in a bias of MSCs toward the adipose lineage at the expense of bone $(81,95)$. Remarkably the effects of prenatal TBT exposure could be transmitted to subsequent generations. Exposure of pregnant FO dams to environmentally relevant (nanomolar) levels of TBT in the drinking water led to increases in adipose depot weight, adipocyte size, adipocyte number and the propensity of MSCs to differentiate along the adipogenic rather than the osteogenic pathways in F1, F2 and F3 offspring (96). Transgenerational increases in obesity were also reported with different chemicals in other laboratories (97, 98, $99,100,101)$. The data indicated that these effects were likely mediated by an epigenetic process. A subsequent experiment using TBT exposure found that the effects of prenatal TBT exposure on fat depot size persisted until at least the F4 generation (102). F4 male descendants of pregnant F0 mice exposed to TBT had increased fat mass in adulthood and gained more fat mass than their control counter parts when dietary fat was increased modestly (from 13.2 to $21.2 \% \mathrm{kcal}$ from fat) (102). Moreover, these animals resisted fat loss during fasting and retained the increased fat when returned to the normal low-fat diet (102).

Multi-'omic analysis of the transcriptome and DNA methylomes from the F4 male mice revealed that there were thousands of differentially methylated regions (DMRs) but that none of these were closely associated with the promoters of genes whose expression was altered. Instead, large regions of DNA where methylation was all in the same direction were identified. These iso-directional differentially methylated blocks were denoted as isoDMBs (102). It was hypothesized that the transgenerational phenotype was carried across generations through the germline by altered higher order chromatin structure (102, 103). ATAC-seq analysis of F3 and F4 sperm demonstrated

This work is licensed under a Creative Commons Attribution-NonCommercial-NoDerivatives 4.0 International License.ifica, com at $04 / 26 / 2023 \quad 10: 46: 40 \mathrm{Am}$ 
that the DNA regions containing hypomethylated isoDMBs in F4 male WAT were less accessible in sperm chromatin and preferentially associated with DNA having elevated GC content (102). These regions that were enriched in hypomethylated isoDMBs and higher GC content contained many metabolically relevant genes, as did the inaccessible regions in sperm DNA (102). Expression of leptin mRNA in WAT was elevated, as were circulating levels of leptin protein in male mice and it was inferred that the animals displayed a leptin-resistant, thrifty phenotype promoted by altered higher order chromatin structure (102). Subsequent studies supported and extended this model, demonstrating that this disrupted chromatin organization is either transmitted directly to subsequent generations, or (more likely) selfreconstructs each generation (103).

An important aspect to be considered in light of the transgenerational effects of TBT and other obesogens is that since current toxicology risk assessment paradigms involve direct exposure to chemicals, they may fail to identify the hazards associated with chemical exposure comprehensively. Indeed, directly exposed generations may exhibit few or no significant phenotypes, and it has been argued that risks would be best assessed by complementing classic toxicology analysis with the assessment of the impacts on future generations, referred to as 'generational toxicology' (104).

\section{Obesogens, old and new}

A variety of chemicals have been demonstrated to be obesogenic in animal studies. These include such widely used chemicals as phthalates, bisphenols, parabens, flame retardants, and pesticides. This topic has been reviewed extensively elsewhere (e.g. 16, 105, 106). Below we discuss some long-known chemicals that were newly discovered as obesogens and potential obesogens of current interest. A list of verified and potential obesogens and their putative mechanisms of action are presented in Tables 1 and 2 .

\section{Acrylamide}

Acrylamide is found in foods and can be formed as an unintentional byproduct of frying, baking, or roasting; this is likely to be the most common source of human exposure (107). Acrylamide exposure was found to induce the accumulation of WAT in male mice but only after they were fed a high-fat diet (108). Mechanistic analysis revealed that acrylamide acted through the MAPK and
AMPK-ACC pathways to promote adipogenesis (108). Crucially, similar effects have been found in human epidemiology studies. Findings from two longitudinal birth cohort studies from France (109) and Norway (110) proposed hemoglobin adducts of acrylamide (HbAA) and glycidamide (HbGA) as biomarkers of acrylamide exposure in humans. These studies found that children prenatally exposed to higher levels of acrylamide were more likely to be born small for gestational age and obese at 3 years of age. Cross-sectional analysis of NHANES data (2003-2006) demonstrated a negative association between HbAA and obesity but a positive association between HbGA levels and obesity (111). A different cross-sectional analysis of NHANES data (2003-2004) found a negative association to obesity for HbAA and no association with HbGA (112). While it is interesting and provocative that acrylamide has been associated with obesity, there are clearly confounding factors in these data sets that must be resolved to establish whether or not acrylamide exposure is linked with obesity. Considering the extensive exposure of the population to acrylamide from baked and fried foods, further exploration of these issues will be very important for public health.

\section{Food additives}

As noted above, increasing evidence has emerged linking components of the 'Western dietary pattern' to obesity, even finding that the total number of carbohydrate calories is less important than whether the calories come from whole or processed foods $(5,6)$. In this light, it is interesting that recent data showed that some commonly used food additives have obesogenic potential. Two common dietary emulsifiers, carboxylmethylcellulose and P-80 induced intestinal inflammation and disrupted the gut microbiome producing increased body weight, WAT depot weight and metabolic syndrome when administered either to young (4-week-old) mice for 12 weeks, or to old (16-week-old) mice for 8 weeks (113). Dioctyl sodium sulfosuccinate (DOSS) is also used as a dietary emulsifier, and as a major component of an over the counter stool softener (Colace/Docusate). DOSS was shown to bind PPAR $\gamma$ ligand-binding domain with an affinity comparable to that of pioglitazone and arachidonic acid, act as a PPAR $\gamma$ agonist in reporter assays and induce adipogenesis in 3T3-L1 preadipocytes (114). Moreover, male offspring of mice exposed to a clinically relevant dose of DOSS during pregnancy exhibited increased body mass, increased adiposity, glucose intolerance and hyperinsulinemia when fed standard diet (115). 


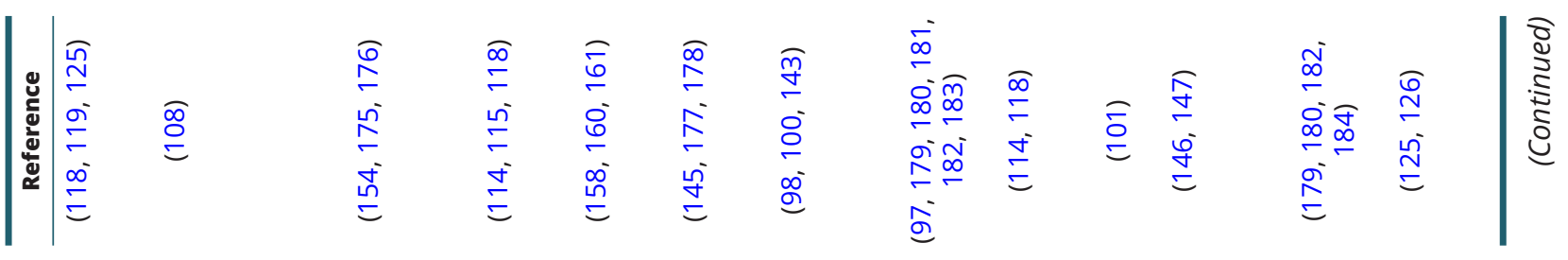

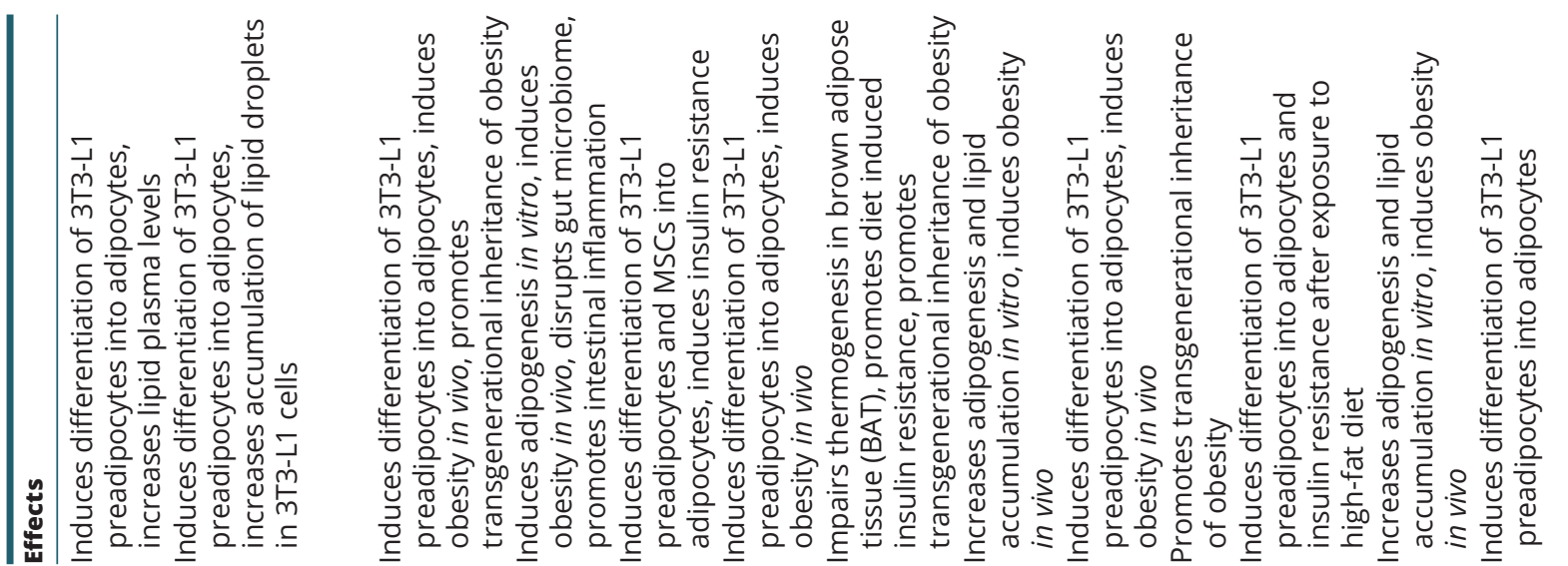
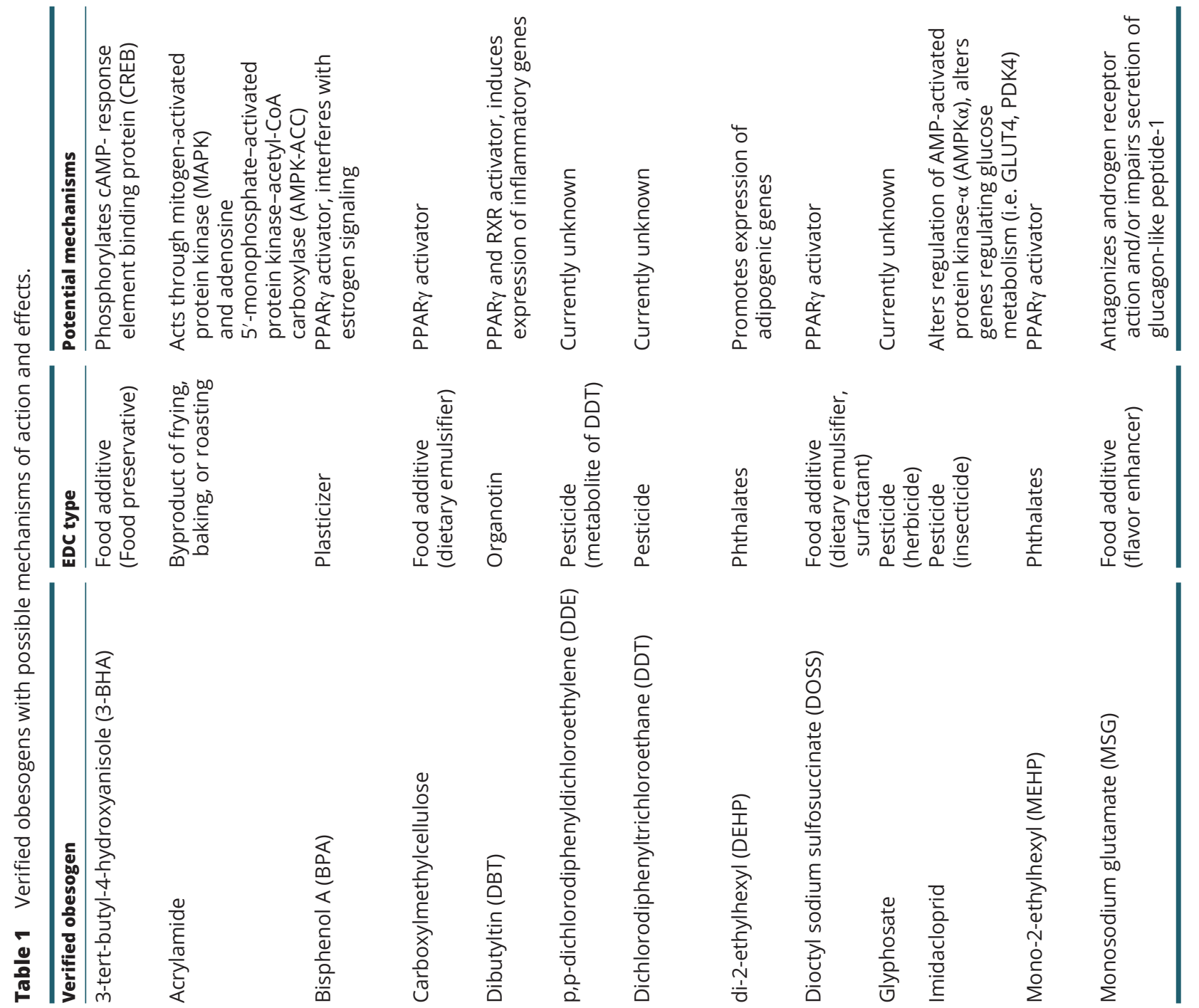


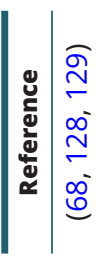

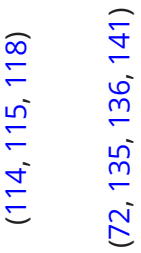
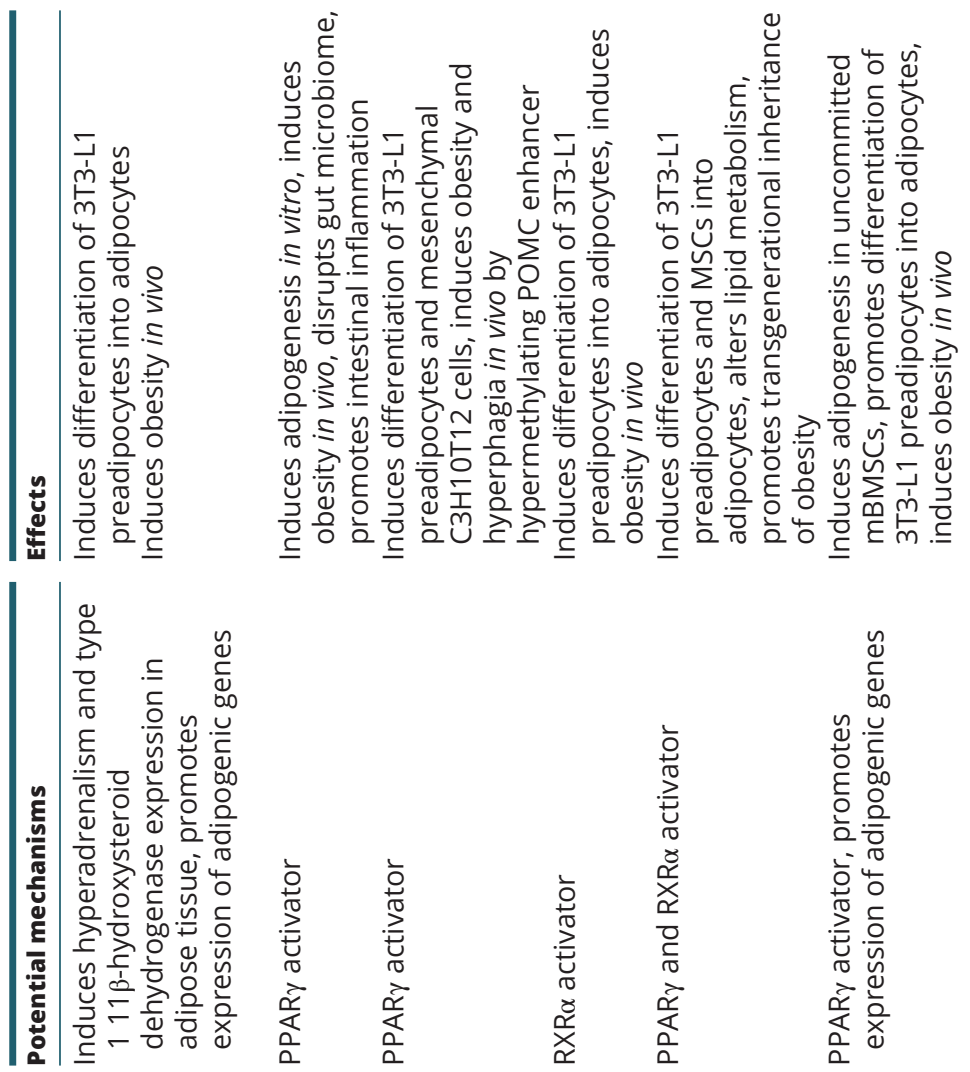

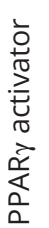

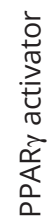

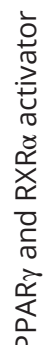
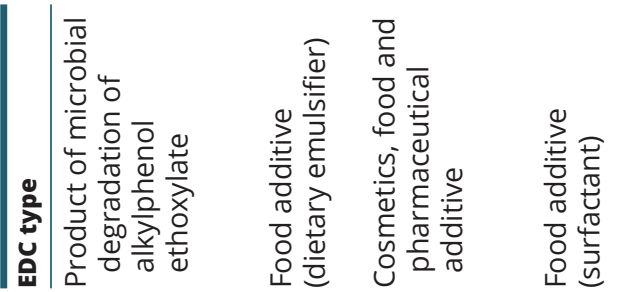

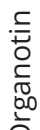

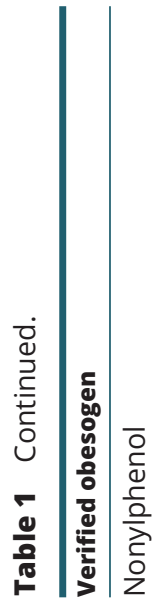

$\stackrel{-10}{-10}$

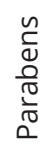

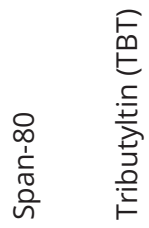

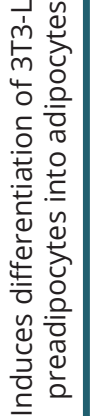

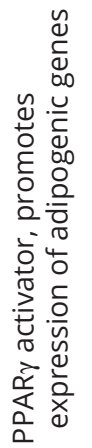

$\frac{0}{0}$

\begin{tabular}{l|l}
$x$ \\
0 \\
0
\end{tabular}
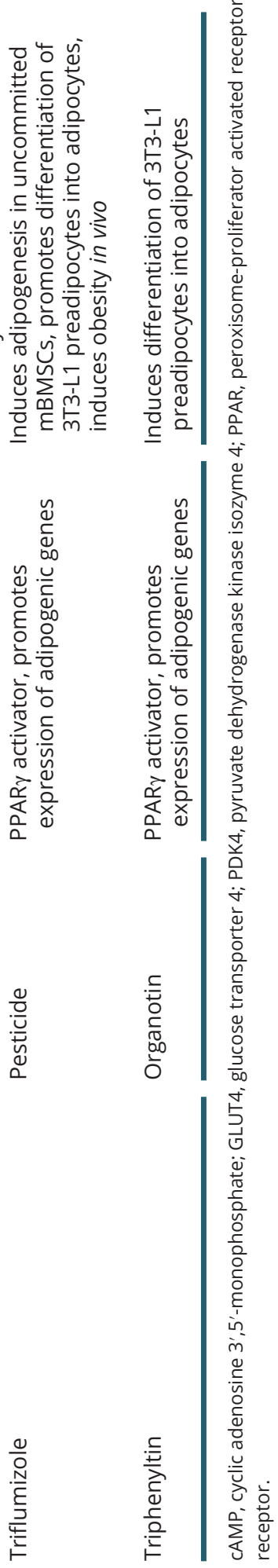
Table 2 Potential obesogens with possible mechanisms of action and effects.

mBMSCs, mouse bone marrow-derived stem cells; PPAR, peroxisome-proliferator activated receptor.

https://ec.bioscientifica.com https://doi.org/10.1530/EC-20-0578 (c) 2021 The authors Published by Bioscientifica Ltd

\begin{tabular}{|c|c|c|c|c|}
\hline Potential obesogen & EDC type & Potential mechanisms & Effects & Reference \\
\hline $\begin{array}{l}\text { Alpha } \\
\text { naphthoflavone }\end{array}$ & Pollutant & $\begin{array}{l}\text { AhR antagonist, increased expression } \\
\text { of hormone-sensitive lipase and the } \\
\text { estrogen receptor }\end{array}$ & $\begin{array}{l}\text { Promotes lipid } \\
\text { accumulation in } \\
\text { adipocytes }\end{array}$ & $(186)$ \\
\hline BADGE & Pesticide & PPAR $\gamma$ activator & $\begin{array}{l}\text { Induces differentiation of } \\
\text { 3T3-L1 preadipocytes } \\
\text { and MSCs into adipocytes }\end{array}$ & (187) \\
\hline BBP & Pesticide & PPAR $\gamma$ activator & $\begin{array}{l}\text { Increased lipid } \\
\text { accumulation in vitro }\end{array}$ & $(182,188)$ \\
\hline Bisphenol F (BPF) & $\begin{array}{l}\text { Plasticizer } \\
\text { (BPA analog) }\end{array}$ & PPAR $\gamma$ activator & $\begin{array}{l}\text { Induces differentiation of } \\
\text { preadipocytes into } \\
\text { adipocytes }\end{array}$ & $(149,154,155)$ \\
\hline Bisphenol S (BPS) & $\begin{array}{l}\text { Plasticizer } \\
\text { (BPA analog) }\end{array}$ & $\begin{array}{l}\text { PPAR } \gamma \text { activator, upregulates adipogenic } \\
\text { mRNA expression levels (i.e. } \\
\text { Lipoprotein Lipase, CAAT/enhancer- } \\
\text { binding proteins } \beta \text { (C/EBP } \beta \text { ) }\end{array}$ & $\begin{array}{l}\text { Induces differentiation of } \\
\text { preadipocytes into } \\
\text { adipocytes }\end{array}$ & $(149,154,155)$ \\
\hline Diazinon & Pesticide & $\begin{array}{l}\text { PPAR } \gamma \text { activator, activates CCAAT- } \\
\text { enhancer binding protein CAAT/ } \\
\text { enhancer- binding proteins } \alpha(\text { C/EBP } \alpha)\end{array}$ & $\begin{array}{l}\text { Induces differentiation of } \\
\text { 3T3-L1 preadipocytes } \\
\text { into adipocytes }\end{array}$ & (189) \\
\hline Diclofop-methyl & Pesticide & PPAR $\gamma$ activator & $\begin{array}{l}\text { Induces adipogenesis in } \\
\text { human adipose-derived } \\
\text { stromal cells }\end{array}$ & (75) \\
\hline Fentin hydroxide & Pesticide & PPAR $\gamma$ activator & $\begin{array}{l}\text { Increases adipogenesis } \\
\text { and lipid accumulation } \\
\text { in vitro }\end{array}$ & $(75,78)$ \\
\hline Forchlorfenuron & Pesticide & $\begin{array}{l}\text { Promotes expression of adipogenic } \\
\text { genes }\end{array}$ & $\begin{array}{l}\text { Induces differentiation of } \\
\text { 3T3- L1 preadipocytes } \\
\text { into adipocytes }\end{array}$ & (76) \\
\hline Fludioxonil & Pesticide & $\begin{array}{l}\text { PPAR } \gamma \text { and RXR } \alpha \text { activator, promotes } \\
\text { expression of adipogenic genes }\end{array}$ & $\begin{array}{l}\text { Induces adipogenesis in } \\
\text { uncommitted mBMSCs, } \\
\text { promotes differentiation } \\
\text { of 3T3-L1 preadipocytes } \\
\text { and MSCs into adipocytes }\end{array}$ & $(75,76)$ \\
\hline Flusilazole & Pesticide & $\begin{array}{l}\text { Promotes expression of adipogenic } \\
\text { genes }\end{array}$ & $\begin{array}{l}\text { Induces differentiation of } \\
\text { 3T3-L1 preadipocytes } \\
\text { into adipocytes }\end{array}$ & (76) \\
\hline Halosulfuron-methyl & Pesticide & PPAR $\gamma$ activator & $\begin{array}{l}\text { Induces adipogenesis in } \\
\text { human adipose-derived } \\
\text { stromal cells }\end{array}$ & (75) \\
\hline Lactofen & Pesticide & PPAR $\gamma$ activator & $\begin{array}{l}\text { Induces adipogenesis in } \\
\text { human adipose-derived } \\
\text { stromal cells }\end{array}$ & (75) \\
\hline Quinoxyfen & Pesticide & PPAR $\gamma$ activator & $\begin{array}{l}\text { Induces adipogenesis in } \\
\text { uncommitted mBMSCs, } \\
\text { promotes differentiation } \\
\text { of 3T3-L1 preadipocytes } \\
\text { into adipocytes }\end{array}$ & (76) \\
\hline Quizalofop-p-ethyl & $\begin{array}{l}\text { Pesticide } \\
\text { (herbicide) }\end{array}$ & Currently unknown & $\begin{array}{l}\text { Induces differentiation of } \\
\text { 3T3-L1 preadipocytes } \\
\text { into adipocytes }\end{array}$ & $(148)$ \\
\hline Spirodiclofen & Pesticide & $\begin{array}{l}\text { PPAR } \gamma \text { activator, promotes expression } \\
\text { of adipogenic genes in vitro }\end{array}$ & $\begin{array}{l}\text { Induces differentiation of } \\
\text { 3T3-L1 preadipocytes } \\
\text { and mBMSCs into } \\
\text { adipocytes }\end{array}$ & (76) \\
\hline Tebupirimfos & Pesticide & $\begin{array}{l}\text { Promotes expression of adipogenic } \\
\text { genes }\end{array}$ & $\begin{array}{l}\text { Induces differentiation of } \\
\text { 3T3-L1 preadipocytes into } \\
\text { adipocytes }\end{array}$ & (76) \\
\hline Zoxamide & Pesticide & PPAR $y$ activator & $\begin{array}{l}\text { Induces differentiation of } \\
\text { 3T3-L1 preadipocytes and } \\
\text { mBMSCs into adipocytes }\end{array}$ & (76) \\
\hline
\end{tabular}
f hormone-sensitive lipase and the PAR activator mRNA expression levels (i.e. ( PAR $\gamma$ activator, activates CCAAT ancer binding protein CAAT/ enhancer- binding proteins $\alpha($ C/EBP $\alpha)$ nduces adipogenesis in human adipose-derived and lipid accumulation duces differentiation of 3T3-L1 preadipocytes and MSCs into adipocytes into adipocytes nduces adipogenesis in stromal cells Induces adipogenesis in human adipose-derived promotes differentiation of 3T3-L1 preadipocytes 3T3-L1 preadipocytes 3T3-L1 preadipocytes and mBMSCs into adipocytes 3T3-L1 preadipocytes and mBMSCs into adipocytes

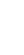

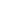


DOSS was used together with another surfactant, Span-80, in the COREXIT dispersants that were used in the clean-up of the Deepwater Horizon oil spill in 2010 (116). Span-80 activated $\mathrm{RXR} \alpha$ and induced 3T3-L1 preadipocytes to differentiate into adipocytes (117). When 3T3-L1 cells were treated with a combination of Span-80 and DOSS, adipogenic induction was greater than with either chemical individually (117).

In addition to surfactants and emulsifiers, the widely used food preservative 3-tert-butyl-4-hydroxyanisole (3-BHA) induced adipocyte differentiation in 3T3-L1 preadipocytes (118); moreover, 3-BHA exposure increased adiposity and lipid plasma levels in exposed mice (119). The flavor enhancer monosodium glutamate (MSG) is well-known for its action to induce obesity and metabolic abnormalities in mice by its toxic effects on the arcuate nucleus, a critical hypothalamic nucleus involved in body mass and energy metabolism regulation $(120,121$, $122,123)$. Notably, the central effects of MSG to promote obesity depend upon its entrance in the brain, which, in turn, is observed when it is administered centrally to adult mice or peripherally to neonate mice since the latter exhibit an immature blood-brain barrier allowing the passage of MSG (123, 124). More recently, it was shown that MSG might act by additional mechanisms that may mediate its obesogen effect. Such actions include impairment of glucagon-like peptide-1 (GLP-1) secretion, an important hormone regulating appetite, by the enteroendocrine cell line STC-1, (125) and/or androgen receptor action antagonism (126). Considering these results together, it is perhaps not at all surprising that highly processed foods lead to more weight gain than the same number of calories from fresh foods $(5,6)$. This will be an important area for future laboratory and epidemiological studies.

\section{Nonylphenol}

Nonylphenol is the main microbial degradation product of alkylphenol ethoxylate, a nonionic surfactant used to manufacture a wide range of products, such as plastics, pesticides, and cosmetics (127). In vitro, nonylphenol induces the differentiation of 3T3-L1 preadipocytes into adipocytes $(69,128)$. Prenatal exposure to nonylphenol induced increased body weight, fat mass, and fasting serum glucose and total cholesterol levels (68). The obese phenotype was more pronounced in the female offspring than in males and occurred at lower exposure concentrations (68). A similar finding was reported in the male offspring of rats exposed to nonylphenol during pregnancy (129). Despite its well-known estrogenic activity (130), estrogenic receptor signaling has not been directly linked to its obesogenic action. Nonylphenol was shown to induce hyperadrenalism and increase type 1 $11 \beta$-hydroxysteroid dehydrogenase in adipose tissue in vivo, which could be linked to the obese phenotype (129). However, the molecular mechanisms underlying the obesogenic effect of nonylphenol remain elusive.

Although nonylphenol is considered a persistent and ubiquitous environment contaminant (131, 132) with obesogenic properties, very few human studies have addressed its association with body mass. A cross-sectional study from Taiwan involving 270 adolescents found no association between urinary nonylphenol levels and anthropometric measures of overall or abdominal obesity (133). Therefore, further studies will be necessary to establish whether this chemical is associated with obesity in humans and the mechanisms underlying its effects.

\section{Parabens}

Parabens are used as preservatives in pharmaceuticals, food, and cosmetic products due to their antimicrobial and antifungal properties. Cosmetic and personal care products seem to be a significant source of human exposure since parabens are found in most rinse-off or leave-on products (134). Parabens were shown to promote adipogenesis in 3T3-L1 preadipocytes $(72,135)$ and mesenchymal C3H10T1/2 cells (136) by activating PPAR $\gamma$ (72, 136). Accordingly, parabens reduced osteogenic and chondrogenic differentiation of C3H10T1/2 cells (136).

Previous cross-sectional and longitudinal human studies addressed exposure to parabens during adulthood (137) or after the early postnatal period $(137,138,139,140)$ and found an inconsistent association with overweight and obesity. More recently, a longitudinal study involving 496 mother-children pairs of the German LINA cohort (Lifestyle and Environmental Factors and their Influence on Newborns Allergy Risk) reported that maternal exposure to butyl paraben at the third trimester of pregnancy was associated with child overweight during the first 8 years of life, with a stronger trend among girls (141). The authors reproduced the human findings in mice exposed to butyl paraben during fetal life and reported that exposure of female human adipose-derived mesenchymal stem cells to butyl paraben did not induce adipogenesis (141). Mechanistic analysis using the in vivo model revealed that early-life exposure to butyl paraben induced higher food intake in the female offspring (141). This finding was

This work is licensed under a Creative Commons Attribution-NonCommercial-NoDerivatives 4.0 Internationad bicense.ifica.com at 04/26/2023 10:46:40AM 
accompanied by reduced hypothalamic mRNA expression of the gene encoding proopiomelanocortin (POMC) due to hypermethylation of POMC enhancer nPE1, which positively regulates POMC transcription (141). Given the broad human exposure to parabens, further efforts to expand this investigation to other parabens and populations are warranted.

\section{Pesticides}

In addition to food additives, agrochemicals that contaminate food have been linked to obesity in animals and in humans. This topic has been intensively reviewed elsewhere (67) and will be summarized here. One very important example is the well-known organochlorine pesticide dichlorodiphenyltrichloroethane (DDT). DDT was shown to be obesogenic in rodent models, and its effects were dependent upon the timing of exposure and gender. Perinatal exposure of mice to DDT reduced energy expenditure and transiently increased body fat content in female offspring (142). Moreover, ancestral exposure to DDT lead to obesity and metabolic abnormalities in male and female rats from the F3 generation, characterizing a transgenerational obese phenotype (98). Human studies have also reported that perinatal exposure to DDT is associated with increased obesity risk during childhood (143) and adult life (144). The major breakdown product of DDT, p,p-dichlorodiphenyldichloroethylene DDE was associated with weight gain in multiple human studies (145). The use of DDT was banned under the Stockholm Convention but it persists in the environment and continues to be used for malaria control in Africa. Methoxychlor was intended to replace DDT, but was shown to induce obesity in rats (100). Several other pesticides have been identified as being actually, or potentially obesogenic. The neonicotinoid insecticide, imidacloprid induced 3T3-L1 preadipocytes to differentiate into adipocytes (146) and promoted obesity in mice exposed to a high-fat diet (147). The widely used and controversial herbicide, glyphosate, induced obesity in F2 and F3 offspring of F0 female rats exposed during gestation (101). Many other agrochemicals induced adipogenesis in 3T3-L1 preadipocytes and in mouse and human MSCs (75, 76, 148). While the potential of these chemicals to promote obesity, in vivo, remains unexplored at present, the next chemical found to induce adipogenesis in cell models but that fails to promote obesity, in vivo, will be the first. The intensive use of agrochemicals worldwide and the ubiquitous human exposure via food consumption indicates that it will be important to undertake appropriate studies in human cohorts and in animal models to understand the magnitude of the potential risk posed by these chemicals.

\section{Other bisphenols}

As a result of public demand for BPA-free plastics, industry has responded by producing a variety of BPA relatives for use in plastics and in thermal papers. These include over 20 chemicals, such as bisphenol S (BPS), bisphenol F (BPF), bisphenol B, bisphenol E, bisphenol AF, bisphenol $\mathrm{Z}$ among others. These are coming into widespread use as industry strives to produce products with similar physicochemical properties to BPA-based plastics while not totally disrupting current manufacturing processes (149). Much less is known about the potential EDC effects of these BPA analogs, although some of them have been described as obesogens in vitro and in animal models, and associated with increased body mass in humans (150). Some evidence shows that BPS and BPF have similar endocrine-disrupting properties to BPA $(151,152,153)$. Halogenated BPA analogs as well as BPS were more potent activators of PPAR $\gamma$ (154) and were stronger promoters of adipogenesis in 3T3-L1 preadipocytes than BPA (155). Perinatal exposure to BPS also elicited obesity in mice (156). A longitudinal birth cohort study revealed that BPS and BPF were significantly associated with obesity in children (ages 6-19), whereas BPA and total bisphenol levels were not significantly associated (157). In contrast, levels of BPA have been significantly associated with obesity incidence, whereas levels for BPS and BPF were not linked with obesity in a cross-sectional study of adults after adjusting for lifestyle and socioeconomic factors (149). Clearly more studies are needed, but the data indicated that BPS and BPF may be 'regrettable substitutes' for BPA in that they may not actually reduce the hazards of bisphenol exposure to humans.

\section{More organotins}

While it is clear that TBT exposure can lead to obesogenic effects, it remains unclear to what extent the human population is exposed. However, there is no question that humans are widely exposed to organotins, in general. Dibutyltin (DBT) is more prevalent in the environment than TBT due to its presence in polyvinyl chloride (PVC) plastics at substantial concentrations (up to $3 \% \mathrm{w} / \mathrm{w}$ ) (158). DBT leaches into drinking water from PVC pipes and, therefore, may produce a hazard to humans (159).

DBT is the major breakdown product of TBT in vivo.

\footnotetext{
This work is licensed under a Creative Commons Attribution-NonCommercial-NoDerivatives 4.0 International dicense ifica. com at 04/26/2023 10:46:40AM 
DBT activated the same receptors as does TBT and induced 3T3-L1 preadipocytes (160) and human and mouse MSCs to differentiate into adipocytes (161). Perinatal exposure to DBT, albeit at a higher dose than TBT, led to increased WAT weight in mice comparable to that of the model obesogen TBT (161). Unexpectedly, while TBT does not elicit changes in glucose homeostasis, the offspring of DBT-exposed dams were insulin resistant (161). Thus, while DBT can activate similar nuclear receptors as does TBT, it clearly engages additional or alternative cellular mechanisms to elicit insulin resistance.

\section{Future directions}

While the obesogen hypothesis was initially controversial when first proposed in 2006 (162), studies around the world have supported the model and it is becoming evident that obesity is considerably more complex than a simple function of energy balance. Much has been learned about the number and types of obesogens but we need to know much more to assess their overall significance in obesity susceptibility. For example, relatively little is known about how obesogen exposure interacts with macro and micro-nutrients in the diet to promote obesity. Obesogens can affect composition of the microbiome $(163,164)$ and transfer of an obese microbiome itself can cause obesity (21). Very little is known about how obesogen-elicited changes in the microbiome can contribute to obesity. A combination of mechanistic studies in cell and animal models together with longitudinal epidemiological and biomonitoring studies in humans will be required for a full assessment of the risks and costs of EDC and obesogen exposures to public health. While current estimates only consider a few chemicals for which adequate data sets are available, the costs are predicted to be substantial $(165,166)$.

Nearly all studied obesogens exert sexually dimorphic effects. For example, prenatal exposure of pregnant F0 dams to TBT produced increased fat mass in both sexes of the F1 generation, but obesity was only found in males of F2-F4 generations $(96,102,161)$. The synthetic estrogen, diethylstilbestrol, the first chemical to be reported as an obesogen, in vivo, elicited obesity after perinatal exposure adult female but not male mice (167). Many examples of obesogen exposure producing sexually dimorphic effects in animal models exist (reviewed in 17). Relatively little is known about the etiology of these sexual dimorphisms beyond some indications that effects of environmental estrogens may be expected to be more pronounced in females. Notably, while the incidence of obesity is increasing in both sexes in human populations, obesity is significantly more prevalent in females, particularly in the USA (168). Appropriate strategies for intervention and prevention will require a deeper understanding of what cellular pathways mediate obesogen action.

A persistent difficulty in the EDC field is to understand the effects of mixtures. For example, Will exposure to combinations of obesogens result in additive or synergistic effects? ,Or Will they instead interfere with each other's actions? Since many obesogens appear to induce a variety of effects other than obesity, they may be acting through multiple mechanisms. For example, TBT binds to and activates PPAR $\gamma$ and RXR, but it also induces epigenetic modifications and changes to chromatin architecture (102, 103). Some evidence suggests that these changes in chromatin architecture can be transmitted across generations, but the mechanisms remain obscure. A handful of chemicals are known to elicit transgenerational effects on obesity, but we know relatively little about how these effects may be transmitted across generations (reviewed in 104, 106). Nuclear receptor activation can lead to epigenetic alterations $(169,170)$, but there is currently no evidence that nuclear receptor activation is a key component of the mechanism through which obesogens act across generations. It is possible that exposure to a combination of obesogens, each of which may act through a different pathway, will be required to explain the obesity pandemic. In support of this possibility, it is well-known that chemical mixtures can induce higher receptor activation or stronger phenotypes $(171,172,173$, 174). Moreover, the potential of many other obesogens to induce transgenerational obesity remains to be explored.

While much has been revealed about the number and nature of obesogens and some inroads have been made on mechanisms of action, we still know little about the entire spectrum of possible obesogens, how they act and who is exposed to what degree. Understanding how obesogens act will facilitate the identification of other obesogens that may have similar mechanisms of action. It will be crucial to develop and deploy screening assays that are sensitive and reliable enough to identify potential EDCs and obesogens before widespread exposure and adverse outcomes occur, as has been previously discussed (64). The US EPA has developed ToxCast and the National Toxicology Program (in collaboration with EPA) has developed Tox21. These are widely and frequently touted as the future of such screening studies but evidence is growing that the assays may not be sensitive or reliable enough to make effective predictions (76). The European Union has adopted a 
different approach. Under its Horizon 2020 grant program, the EU has funded eight international consortia that aim to establish standardized, internationally harmonized screening methods for EDCs. Three of these consortia are focused on developing methods to identify metabolism disrupting chemicals, including obesogens. Since the assays to identify EDCs will be developed by experts in the field, rather than using repurposed screening assays from the pharmaceutical industry, it is likely that these efforts will bear fruit. Identifying the full spectrum of obesogens and understanding their mechanisms of action will reveal how we can best prevent exposure or reduce the effects of exposure.

Currently, little is known about the magnitude of the obesogen effect in humans, and to what extent it contributes to the obesity pandemics. This would require understanding the effects of obesogens on a 'real life scenario', including exposure to a mixture of chemicals and their interaction with other factors affecting obesity risk, such as genetics, diet, stress, disrupted circadian rhythms combined with a longitudinal study design. Although there is much more to be discovered about obesogens, the advances on the field over the last 15 years have provided enough evidence to support the implementation of the 'precautionary principle' both on a public health and personnel perspective, to protect ourselves and future generations from their harmful impacts.

\section{Declaration of interest}

The authors declare that there is no conflict of interest that could be perceived as prejudicing the impartiality of this review.

\section{Funding}

Supported by grants from the United States National Institutes of Health (R01 ES023316, R01 ES021832, R01 ES031139) to B B, and from the University of Brasilia and the Foundation for Research Support from the Federal District (DGP/UnB 05/2018) to A A A. B B is a named inventor on patents related to PPAR $\gamma$ and other nuclear receptors, none of which presents and actual or apparent conflict. A A A and H B W have nothing to declare.

\section{References}

1 GBDO AA, Forouzanfar MH, Reitsma MB, Sur P, Estep K, Lee A, Marczak L, Mokdad AH, Moradi-Lakeh M, et al. Collaborators. New England Journal of Medicine 2017377 13-27. (https://doi.org/10.1056/ NEJMoa1614362)

2 Flegal KM, Carroll MD, Kit BK \& Ogden CL. Prevalence of obesity and trends in the distribution of body mass index among US adults, 1999-2010. JAMA 2012307 491-497. (https://doi.org/10.1001/ jama.2012.39)
3 Hales C, Carroll M, Fryar CD \& Ogden CL Prevalence of Obesity Among Adults and Youth: United States, 2015-2016. Hyattsville, MD: United States Department of Health \& Human Services. Report 2882017.

4 Ogden CL, Carroll MD, Kit BK \& Flegal KM. Prevalence of childhood and adult obesity in the United States, 2011-2012. JAMA 2014311 806-814. (https://doi.org/10.1001/jama.2014.732)

5 Ludwig DS \& Ebbeling CB. The carbohydrate-insulin model of obesity: beyond "calories in, calories out". JAMA Internal Medicine 2018178 1098-1103. (https://doi.org/10.1001/ jamainternmed.2018.2933)

6 Ludwig DS, Hu FB, Tappy L \& Brand-Miller J. Dietary carbohydrates: role of quality and quantity in chronic disease. BMJ 2018361 k2340. (https://doi.org/10.1136/bmj.k2340)

7 Heini AF \& Weinsier RL. Divergent trends in obesity and fat intake patterns: the American paradox. American Journal of Medicine 1997 102 259-264. (https://doi.org/10.1016/S0002-9343(96)00456-1)

8 Cohen E, Cragg M, deFonseka J, Hite A, Rosenberg M \& Zhou B. Statistical review of US macronutrient consumption data, 19652011: Americans have been following dietary guidelines, coincident with the rise in obesity. Nutrition 201531 727-732. (https://doi. org/10.1016/j.nut.2015.02.007)

9 Shan Z, Rehm CD, Rogers G, Ruan M, Wang DD, Hu FB, Mozaffarian D, Zhang FF \& Bhupathiraju SN. Trends in dietary carbohydrate, protein, and fat intake and diet quality Among US adults, 1999-2016. JAMA 2019322 1178-1187. (https://doi. org/10.1001/jama.2019.13771)

10 Brown RE, Sharma AM, Ardern CI, Mirdamadi P, Mirdamadi P $\&$ Kuk JL. Secular differences in the association between caloric intake, macronutrient intake, and physical activity with obesity. Obesity Research \& Clinical Practice 201610 243-255. (https://doi. org/10.1016/j.orcp.2015.08.007)

11 Church TS, Thomas DM, Tudor-Locke C, Katzmarzyk PT, Earnest CP, Rodarte RQ, Martin CK, Blair SN \& Bouchard C. Trends over 5 decades in U.S. occupation-related physical activity and their associations with obesity. PLOS ONE 20116 e19657. (https://doi. org/10.1371/journal.pone.0019657)

12 Maes HHM, Neale MC \& Eaves LJ. Genetic and environmental factors in relative body weight and human adiposity. Behavior Genetics 1997 27 325-351. (https://doi.org/10.1023/a:1025635913927)

13 Zaitlen N, Kraft P, Patterson N, Pasaniuc B, Bhatia G, Pollack S \& Price AL. Using extended genealogy to estimate components of heritability for 23 quantitative and dichotomous traits. PLOS Genetics 20139 e1003520. (https://doi.org/10.1371/journal.pgen.1003520)

14 Goodarzi MO. Genetics of obesity: what genetic association studies have taught us about the biology of obesity and its complications. Lancet. Diabetes \& Endocrinology 20186 223-236. (https://doi. org/10.1016/S2213-8587(17)30200-0)

15 Locke AE, Kahali B, Berndt SI, Justice AE, Pers TH, Day FR, Powell C, Vedantam S, Buchkovich ML, Yang J, et al. Genetic studies of body mass index yield new insights for obesity biology. Nature $2015 \mathbf{5 1 8}$ 197-206. (https://doi.org/10.1038/nature14177)

16 Heindel JJ \& Blumberg B. Environmental obesogens: mechanisms and controversies. Annual Review of Pharmacology and Toxicology 201959 89-106. (https://doi.org/10.1146/annurev-pharmtox-010818-021304)

17 Heindel JJ, Blumberg B, Cave M, Machtinger R, Mantovani A, Mendez MA, Nadal A, Palanza P, Panzica G, Sargis R, et al. Metabolism disrupting chemicals and metabolic disorders. Reproductive Toxicology 201768 3-33. (https://doi.org/10.1016/j. reprotox.2016.10.001)

18 Torres SJ \& Nowson CA. Relationship between stress, eating behavior, and obesity. Nutrition 200723 887-894. (https://doi.org/10.1016/j. nut.2007.08.008)

19 Froy O. Metabolism and circadian rhythms-implications for obesity. Endocrine Reviews 201031 1-24. (https://doi.org/10.1210/er.20090014) https://ec.bioscientifica.com https://doi.org/10.1530/EC-20-0578
(C) 2021 The authors Published by Bioscientifica Ltd
This work is licensed under a Creative Commons Attribution-NonCommercial-NoDerivatives 4.0 elnternational License.ifica com at $04 / 26 / 2023$ 10:46:40AM 
20 Tilg H \& Kaser A. Gut microbiome, obesity, and metabolic dysfunction. Journal of Clinical Investigation $20111212126-2132$. (https://doi.org/10.1172/JCI58109)

21 Turnbaugh PJ, Ley RE, Mahowald MA, Magrini V, Mardis ER \& Gordon JI. An obesity-associated gut microbiome with increased capacity for energy harvest. Nature 2006444 1027-1031. (https:// doi.org/10.1038/nature05414)

22 Zhang X, Zhao H, Chow WH, Bixby M, Durand C, Markham C \& Zhang K. Population-based study of traffic-related air pollution and obesity in Mexican Americans. Obesity 202028 412-420. (https:// doi.org/10.1002/oby.22697)

23 Chaix A, Zarrinpar A, Miu P \& Panda S. Time-restricted feeding is a preventative and therapeutic intervention against diverse nutritional challenges. Cell Metabolism 201420 991-1005. (https://doi. org/10.1016/j.cmet.2014.11.001)

24 World Health Organization Obesity and Overweight. Report 2019.

25 Ibrahim MM. Subcutaneous and visceral adipose tissue: structural and functional differences. Obesity Reviews 201011 11-18. (https:// doi.org/10.1111/j.1467-789X.2009.00623.x)

26 Jung UJ \& Choi MS. Obesity and its metabolic complications: the role of adipokines and the relationship between obesity, inflammation, insulin resistance, dyslipidemia and nonalcoholic fatty liver disease. International Journal of Molecular Sciences 201415 6184-6223. (https://doi.org/10.3390/ijms15046184)

27 Ahmadian M, Duncan RE, Jaworski K, Sarkadi-Nagy E \& Sul HS. Triacylglycerol metabolism in adipose tissue. Future Lipidology 20072 229-237. (https://doi.org/10.2217/17460875.2.2.229)

28 Hausman DB, DiGirolamo M, Bartness TJ, Hausman GJ \& Martin RJ. The biology of white adipocyte proliferation. Obesity Reviews 20012 239-254. (https://doi.org/10.1046/j.1467-789x.2001.00042.x)

29 Spalding KL, Arner E, Westermark PO, Bernard S, Buchholz BA, Bergmann O, Blomqvist L, Hoffstedt J, Naslund E, Britton T, et al. Dynamics of fat cell turnover in humans. Nature $2008 \mathbf{4 5 3}$ 783-787. (https://doi.org/10.1038/nature06902)

30 White U \& Ravussin E. Dynamics of adipose tissue turnover in human metabolic health and disease. Diabetologia 201962 17-23. (https://doi.org/10.1007/s00125-018-4732-x)

31 Tchoukalova YD, Votruba SB, Tchkonia T, Giorgadze N, Kirkland JL \& Jensen MD. Regional differences in cellular mechanisms of adipose tissue gain with overfeeding. Proceedings of the National Academy of Sciences of the United States of America 2010107 18226-18231. (https://doi.org/10.1073/pnas.1005259107)

32 White UA, Fitch MD, Beyl RA, Hellerstein MK \& Ravussin E. Differences in in vivo cellular kinetics in abdominal and femoral subcutaneous adipose tissue in women. Diabetes 201665 1642-1647. (https://doi.org/10.2337/db15-1617)

33 Tchoukalova YD, Koutsari C, Karpyak MV, Votruba SB, Wendland E \& Jensen MD. Subcutaneous adipocyte size and body fat distribution. American Journal of Clinical Nutrition 200887 56-63. (https://doi. org/10.1093/ajcn/87.1.56)

34 Carsley S, Tu K, Parkin PC, Pullenayegum E \& Birken CS. Overweight and obesity in preschool aged children and risk of mental health service utilization. International Journal of Obesity 201943 1325-1333. (https://doi.org/10.1038/s41366-018-0280-1)

35 Dixon JB. The effect of obesity on health outcomes. Molecular and Cellular Endocrinology 2010316 104-108. (https://doi.org/10.1016/j. mce.2009.07.008)

36 Cawley J \& Meyerhoefer C. The medical care costs of obesity: an instrumental variables approach. Journal of Health Economics 201231 219-230. (https://doi.org/10.1016/j.jhealeco.2011.10.003)

37 Biener A, Cawley J \& Meyerhoefer C. The high and rising costs of obesity to the US health care system. Journal of General Internal Medicine 201732 6-8. (https://doi.org/10.1007/s11606-016-3968-8)

38 Klimentidis YC, Beasley TM, Lin HY, Murati G, Glass GE, Guyton M, Newton W, Jorgensen M, Heymsfield SB, Kemnitz J, et al. Canaries in the coal mine: a cross-species analysis of the plurality of obesity

Published by Bioscientifica Ltd epidemics. Proceedings. Biological Sciences 2011278 1626-1632. (https://doi.org/10.1098/rspb.2010.1890)

39 Ravelli GP, Stein ZA \& Susser MW. Obesity in young men after famine exposure in utero and early infancy. New England Journal of Medicine 1976295 349-353. (https://doi.org/10.1056/ NEJM197608122950701)

40 Rogers JM. Smoking and pregnancy: epigenetics and developmental origins of the metabolic syndrome. Birth Defects Research 2019111 1259-1269. (https://doi.org/10.1002/bdr2.1550)

41 Plagemann A. Perinatal programming and functional teratogenesis: impact on body weight regulation and obesity. Physiology and Behavior 200586 661-668. (https://doi.org/10.1016/j. physbeh.2005.08.065)

42 Hanson MA \& Gluckman PD. Developmental origins of health and disease--global public health implications. Best Practice \& Research. Clinical Obstetrics \& Gynaecology 201529 24-31. (https://doi. org/10.1016/j.bpobgyn.2014.06.007)

43 Hales CN \& Barker DJ. The thrifty phenotype hypothesis. British Medical Bulletin 200160 5-20. (https://doi.org/10.1093/bmb/60.1.5)

44 Gluckman PD, Hanson MA \& Beedle AS. Early life events and their consequences for later disease: a life history and evolutionary perspective. American Journal of Human Biology 200719 1-19. (https://doi.org/10.1002/ajhb.20590)

45 Hanson M \& Gluckman P. Developmental origins of noncommunicable disease: population and public health implications. American Journal of Clinical Nutrition 2011 94(Supplement) 1754S-1758S. (https://doi.org/10.3945/ ajcn.110.001206)

46 Hanson MA \& Gluckman PD. Early developmental conditioning of later health and disease: physiology or pathophysiology? Physiological Reviews 201494 1027-1076. (https://doi.org/10.1152/ physrev.00029.2013)

47 Barker DJP. Sir Richard Doll Lecture. Developmental origins of chronic disease. Public Health 2012126 185-189. (https://doi. org/10.1016/j.puhe.2011.11.014)

48 Painter RC, Roseboom TJ \& Bleker OP. Prenatal exposure to the Dutch famine and disease in later life: an overview. Reproductive Toxicology 200520 345-352. (https://doi.org/10.1016/j. reprotox.2005.04.005)

49 Ornoy A. Prenatal origin of obesity and their complications gestational diabetes, maternal overweight and the paradoxical effects of fetal growth restriction and macrosomia. Reproductive Toxicology 201132 205-212. (https://doi.org/10.1016/j. reprotox.2011.05.002

50 Park S, Jang A \& Bouret SG. Maternal obesity-induced endoplasmic reticulum stress causes metabolic alterations and abnormal hypothalamic development in the offspring. PLOS Biology 202018 e3000296. (https://doi.org/10.1371/journal.pbio.3000296)

51 Zoeller RT, Brown TR, Doan LL, Gore AC, Skakkebaek NE, Soto AM, Woodruff TJ \& Vom Saal FS. Endocrine-disrupting chemicals and public health protection: a statement of principles from the Endocrine Society. Endocrinology 2012153 4097-4110. (https://doi. org/10.1210/en.2012-1422)

52 La Merrill MA, Vandenberg LN, Smith MT, Goodson W, Browne P, Patisaul HB, Guyton KZ, Kortenkamp A, Cogliano VJ, Woodruff TJ, et al. Consensus on the key characteristics of endocrine-disrupting chemicals as a basis for hazard identification. Nature Reviews. Endocrinology 202016 45-57. (https://doi.org/10.1038/s41574-0190273-8)

53 Godfray HCJ, Stephens AEA, Jepson PD, Jobling S, Johnson AC, Matthiessen P, Sumpter JP, Tyler CR \& McLean AR. A restatement of the natural science evidence base on the effects of endocrine disrupting chemicals on wildlife. Proceedings. Biological Sciences 2019 286 20182416. (https://doi.org/10.1098/rspb.2018.2416)

54 Papalou O, Kandaraki EA, Papadakis G \& Diamanti-Kandarakis E. Endocrine disrupting chemicals: an occult mediator of metabolic

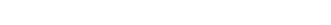

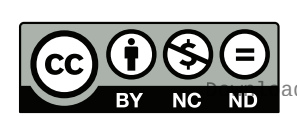

This work is licensed under a Creative Commons Attribution-NonCommercial-NoDerivatives 4.0 Iffternational License ifica. com at 04/26/2023 10:46:40AM 
disease. Frontiers in Endocrinology 201910 112. (https://doi. org/10.3389/fendo.2019.00112)

55 Gore AC, Chappell VA, Fenton SE, Flaws JA, Nadal A, Prins GS, Toppari J \& Zoeller RT. EDC-2: the Endocrine Society's second scientific statement on endocrine-disrupting chemicals. Endocrine Reviews 201536 E1-E150. (https://doi.org/10.1210/er.2015-1010)

56 Veiga-Lopez A, Pu Y, Gingrich J \& Padmanabhan V. Obesogenic endocrine disrupting chemicals: identifying knowledge gaps. Trends in Endocrinology and Metabolism 201829 607-625. (https://doi. org/10.1016/j.tem.2018.06.003)

57 Schug TT, Johnson AF, Birnbaum LS, Colborn T, Guillette LJ, Jr, Crews DP, Collins T, Soto AM, Vom Saal FS, McLachlan JA, et al. Minireview: endocrine disruptors: past lessons and future directions. Molecular Endocrinology 201630 833-847. (https://doi.org/10.1210/ me.2016-1096)

58 Weikum ER, Liu X \& Ortlund EA. The nuclear receptor superfamily: a structural perspective. Protein Science 201827 1876-1892. (https:// doi.org/10.1002/pro.3496)

59 Evans RM \& Mangelsdorf DJ. Nuclear receptors, RXR, and the big bang. Cell 2014157 255-266. (https://doi.org/10.1016/j. cell.2014.03.012)

60 Arsenescu V, Arsenescu RI, King V, Swanson H \& Cassis LA. Polychlorinated biphenyl-77 induces adipocyte differentiation and proinflammatory adipokines and promotes obesity and atherosclerosis. Environmental Health Perspectives 2008116 761-768. (https://doi.org/10.1289/ehp.10554)

61 Kanno J. Introduction to the concept of signal toxicity. Journal of Toxicological Sciences 201641 SP105-SP109. (https://doi.org/10.2131/ jts.41.SP105)

62 Committee ES. Scientific Opinion on the hazard assessment of endocrine disruptors: scientific criteria for identification of endocrine disruptors and appropriateness of existing test methods for assessing effects mediated by these substances on human health and the environment. EFSA Journal $2013 \mathbf{1 1} 3132$.

63 Braun JM. Early-life exposure to EDCs: role in childhood obesity and neurodevelopment. Nature Reviews. Endocrinology 201713 161-173. (https://doi.org/10.1038/nrendo.2016.186)

64 Chamorro-Garcia R \& Blumberg B. Current research approaches and challenges in the obesogen field. Frontiers in Endocrinology 201910 167. (https://doi.org/10.3389/fendo.2019.00167)

65 Hakkola J, Tanaka E \& Pelkonen O. Developmental expression of cytochrome P450 enzymes in human liver. Pharmacology and Toxicology 199882 209-217. (https://doi. org/10.1111/j.1600-0773.1998.tb01427.x)

66 Rubin BS, Paranjpe M, DaFonte T, Schaeberle C, Soto AM, Obin M \& Greenberg AS. Perinatal BPA exposure alters body weight and composition in a dose specific and sex specific manner: the addition of peripubertal exposure exacerbates adverse effects in female mice. Reproductive Toxicology 201768 130-144. (https://doi.org/10.1016/j. reprotox.2016.07.020)

67 Ren X-M \& Blumberg B. Agrochemicals and obesity. Molecular and Cellular Endocrinology in press. 2020

68 Hao CJ, Cheng XJ, Xia HF \& Ma X. The endocrine disruptor 4-nonylphenol promotes adipocyte differentiation and induces obesity in mice. Cellular Physiology and Biochemistry 201230 382-394. (https://doi.org/10.1159/000339032)

69 Hines EP, White SS, Stanko JP, Gibbs-Flournoy EA, Lau C \& Fenton SE. Phenotypic dichotomy following developmental exposure to perfluorooctanoic acid (PFOA) in female CD-1 mice: low doses induce elevated serum leptin and insulin, and overweight in midlife. Molecular and Cellular Endocrinology 2009304 97-105. (https:// doi.org/10.1016/j.mce.2009.02.021)

70 Tontonoz P \& Spiegelman BM. Fat and beyond: the diverse biology of PPARgamma. Annual Review of Biochemistry 200877 289-312. (https://doi.org/10.1146/annurev.biochem.77.061307.091829)
71 Janesick A \& Blumberg B. Endocrine disrupting chemicals and the developmental programming of adipogenesis and obesity. Birth Defects Research. Part C, Embryo Today: Reviews 201193 34-50. (https://doi.org/10.1002/bdrc.20197)

72 Pereira-Fernandes A, Demaegdt H, Vandermeiren K, Hectors TL, Jorens PG, Blust R \& Vanparys C. Evaluation of a screening system for obesogenic compounds: screening of endocrine disrupting compounds and evaluation of the PPAR dependency of the effect. PLOS ONE 20138 e77481. (https://doi.org/10.1371/journal. pone.0077481)

73 Pereira-Fernandes A, Vanparys C, Hectors TL, Vergauwen L, Knapen D, Jorens PG \& Blust R. Unraveling the mode of action of an obesogen: mechanistic analysis of the model obesogen tributyltin in the 3T3-L1 cell line. Molecular \& Cellular Endocrinology 2013370 52-64. )doi:10.1016/j.mce.2013.02.011)

74 Punzon I, Latapie V, Le Mevel S, Hagneau A, Jolivet P, Palmier K, Fini JB $\&$ Demeneix BA. Towards a humanized PPARgamma reporter system for in vivo screening of obesogens. Molecular and Cellular Endocrinology 2013374 1-9. (https://doi.org/10.1016/j.mce.2013.04.004)

75 Foley B, Doheny DL, Black MB, Pendse SN, Wetmore BA, Clewell RA, Andersen ME \& Deisenroth C. Editor's highlight: screening ToxCast prioritized chemicals for PPARG function in a human adipose-derived stem cell model of adipogenesis. Toxicological Sciences 2017155 85-100. (https://doi.org/10.1093/ toxsci/kfw186)

76 Janesick AS, Dimastrogiovanni G, Vanek L, Boulos C, ChamorroGarcia R, Tang W \& Blumberg B. On the utility of ToxCast and ToxPi as methods for identifying new obesogens. Environmental Health Perspectives 2016124 1214-1226. (https://doi.org/10.1289/ ehp.1510352)

77 Grun F, Watanabe H, Zamanian Z, Maeda L, Arima K, Cubacha R, Gardiner DM, Kanno J, Iguchi T \& Blumberg B. Endocrine-disrupting organotin compounds are potent inducers of adipogenesis in vertebrates. Molecular Endocrinology 200620 2141-2155. (https://doi. org/10.1210/me.2005-0367)

78 Kanayama T, Kobayashi N, Mamiya S, Nakanishi T \& Nishikawa J. Organotin compounds promote adipocyte differentiation as agonists of the peroxisome proliferator-activated receptor gamma/retinoid $\mathrm{X}$ receptor pathway. Molecular Pharmacology 200567 766-774. (https:// doi.org/10.1124/mol.104.008409)

79 le Maire A, Grimaldi M, Roecklin D, Dagnino S, Vivat-Hannah V, Balaguer P \& Bourguet W. Activation of RXR-PPAR heterodimers by organotin environmental endocrine disruptors. EMBO Rep. 367-373. EMBO Reports 200910 367-373. (https://doi.org/10.1038/ embor.2009.8)

80 Shoucri BM, Hung VT, Chamorro-Garcia R, Shioda T \& Blumberg B. Retinoid $\mathrm{X}$ receptor activation During adipogenesis of female mesenchymal stem cells programs a dysfunctional adipocyte. Endocrinology 2018159 2863-2883. (https://doi.org/10.1210/ en.2018-00056)

81 Kirchner S, Kieu T, Chow C, Casey S \& Blumberg B. Prenatal exposure to the environmental obesogen tributyltin predisposes multipotent stem cells to become adipocytes. Molecular Endocrinology 201024 526-539. (https://doi.org/10.1210/me.2009-0261)

82 Li X, Ycaza J \& Blumberg B. The environmental obesogen tributyltin chloride acts via peroxisome proliferator activated receptor gamma to induce adipogenesis in murine 3T3-L1 preadipocytes. Journal of Steroid Biochemistry and Molecular Biology 2011127 9-15. (https://doi. org/10.1016/j.jsbmb.2011.03.012)

83 Regnier SM, El-Hashani E, Kamau W, Zhang X, Massad NL \& Sargis RM. Tributyltin differentially promotes development of a phenotypically distinct adipocyte. Obesity 201523 1864-1871. (https://doi.org/10.1002/oby.21174)

84 Penza M, Jeremic M, Marrazzo E, Maggi A, Ciana P, Rando G, Grigolato PG \& Di Lorenzo D. The environmental chemical https://ec.bioscientifica.com https://doi.org/10.1530/EC-20-0578
(C) 2021 The authors Published by Bioscientifica Ltd
This work is licensed under a Creative Commons Attribution-NonCommercial-NoDerivatives 4.0 International License.ifica com at $04 / 26 / 2023$ 10:46:40AM 
tributyltin chloride (TBT) shows both estrogenic and adipogenic activities in mice which might depend on the exposure dose. Toxicology and Applied Pharmacology 2011255 65-75. (https://doi. org/10.1016/j.taap.2011.05.017)

85 Zuo Z, Chen S, Wu T, Zhang J, Su Y, Chen Y \& Wang C. Tributyltin causes obesity and hepatic steatosis in male mice. Environmental Toxicology 201126 79-85. (https://doi.org/10.1002/tox.20531)

86 He K, Zhang J \& Chen Z. Effect of tributyltin on the food intake and brain neuropeptide expression in rats. Endokrynologia Polska 201465 485-490. (https://doi.org/10.5603/EP.2014.0068)

87 Meador JP, Sommers FC, Cooper KA \& Yanagida G. Tributyltin and the obesogen metabolic syndrome in a salmonid. Environmental Research 2011111 50-56. (https://doi.org/10.1016/j. envres.2010.11.012)

88 Tingaud-Sequeira A, Ouadah N \& Babin PJ. Zebrafish obesogenic test: a tool for screening molecules that target adiposity. Journal of Lipid Research 201152 1765-1772. (https://doi.org/10.1194/jlr.D017012)

89 Lyssimachou A, Santos JG, Andre A, Soares J, Lima D, Guimaraes L, Almeida CM, Teixeira C, Castro LF \& Santos MM. The mammalian "Obesogen" tributyltin targets hepatic triglyceride accumulation and the transcriptional regulation of lipid metabolism in the liver and brain of zebrafish. PLOS ONE 201510 e0143911. (https://doi. org/10.1371/journal.pone.0143911)

90 Zhang J, Sun P, Kong T, Yang F \& Guan W. Tributyltin promoted hepatic steatosis in zebrafish (Danio rerio) and the molecular pathogenesis involved. Aquatic Toxicology 2016170 208-215. (https://doi.org/10.1016/j.aquatox.2015.11.028)

91 Zhang J, Sun P, Yang F, Kong T \& Zhang R. Tributyltin disrupts feeding and energy metabolism in the goldfish (Carassius auratus). Chemosphere 2016152 221-228. (https://doi.org/10.1016/j. chemosphere.2016.02.127)

92 den Broeder MJ, Moester MJB, Kamstra JH, Cenijn PH, Davidoiu V, Kamminga LM, Ariese F, de Boer JF \& Legler J. Altered adipogenesis in zebrafish larvae following high fat diet and chemical exposure is visualised by stimulated Raman scattering microscopy. International Journal of Molecular Sciences 2017 18. (https://doi.org/10.3390/ ijms18040894)

93 Lyssimachou A, Navarro JC, Bachmann J \& Porte C. Triphenyltin alters lipid homeostasis in females of the ramshorn snail Marisa cornuarietis. Environmental Pollution 2009157 1714-1720. (https:// doi.org/10.1016/j.envpol.2008.12.013)

94 Jordao R, Garreta E, Campos B, Lemos MF, Soares AM, Tauler R $\&$ Barata C. Compounds altering fat storage in Daphnia magna. Science of the Total Environment 2016 545-546 127-136. (https://doi. org/10.1016/j.scitotenv.2015.12.097)

95 Baker AH, Watt J, Huang CK, Gerstenfeld LC \& Schlezinger JJ. Tributyltin engages multiple nuclear receptor pathways and suppresses osteogenesis in bone marrow multipotent stromal cells. Chemical Research in Toxicology 201528 1156-1166. (https://doi. org/10.1021/tx500433r)

96 Chamorro-Garcia R, Sahu M, Abbey RJ, Laude J, Pham N \& Blumberg B. Transgenerational inheritance of increased fat depot size, stem cell reprogramming, and hepatic steatosis elicited by prenatal exposure to the obesogen tributyltin in mice. Environmental Health Perspectives 2013121 359-366. (https://doi.org/10.1289/ ehp.1205701)

97 Manikkam M, Tracey R, Guerrero-Bosagna C \& Skinner MK. Plastics derived endocrine disruptors (BPA, DEHP and DBP) induce epigenetic transgenerational inheritance of obesity, reproductive disease and sperm epimutations. PLOS ONE 20138 e55387. (https://doi. org/10.1371/journal.pone.0055387)

98 Skinner MK, Manikkam M, Tracey R, Guerrero-Bosagna C, Haque M $\&$ Nilsson EE. Ancestral dichlorodiphenyltrichloroethane (DDT) exposure promotes epigenetic transgenerational inheritance of obesity. BMC Medicine 201311 228. (https://doi.org/10.1186/17417015-11-228)
99 Tracey R, Manikkam M, Guerrero-Bosagna C \& Skinner MK. Hydrocarbons (jet fuel JP-8) induce epigenetic transgenerational inheritance of obesity, reproductive disease and sperm epimutations. Reproductive Toxicology 201336 104-116. (https://doi.org/10.1016/j. reprotox.2012.11.011)

100 Manikkam M, Haque MM, Guerrero-Bosagna C, Nilsson EE \& Skinner MK. Pesticide methoxychlor promotes the epigenetic transgenerational inheritance of adult-onset disease through the female germline. PLOS ONE 20149 e102091. (https://doi. org/10.1371/journal.pone.0102091)

101 Kubsad D, Nilsson EE, King SE, Sadler-Riggleman I, Beck D \& Skinner MK. Assessment of glyphosate induced epigenetic transgenerational inheritance of pathologies and sperm epimutations: generational toxicology. Scientific Reports 201996372 (https://doi.org/10.1038/s41598-019-42860-0)

102 Chamorro-Garcia R, Diaz-Castillo C, Shoucri BM, Kach H, Leavitt R, Shioda T \& Blumberg B. Ancestral perinatal obesogen exposure results in a transgenerational thrifty phenotype in mice. Nature Communications 20178 2012. (https://doi.org/10.1038/s41467-01701944-z)

103 Diaz-Castillo C, Chamorro-Garcia R, Shioda T \& Blumberg B. Transgenerational self-reconstruction of disrupted chromatin Organization After Exposure to an environmental stressor in mice. Scientific Reports 20199 13057. (https://doi.org/10.1038/s41598-01949440-2)

104 Nilsson EE, Sadler-Riggleman I \& Skinner MK. Environmentally induced epigenetic transgenerational inheritance of disease. Environmental Epigenetics 20184 dvy016. (https://doi.org/10.1093/ eep/dvy016)

105 Darbre PD. Endocrine disruptors and obesity. Current Obesity Reports 20176 18-27. (https://doi.org/10.1007/s13679-017-0240-4)

106 Lee MK \& Blumberg B. Transgenerational effects of obesogens. Basic \& Clinical Pharmacology \& Toxicology 2019 125(Supplement 3) 44-57. (https://doi.org/10.1111/bcpt.13214)

107 Ruiz P, Faroon O, Mumtaz M \& Wohlers D Toxicological Profile for Acrylamide 2012

108 Lee HW \& Pyo S. Acrylamide induces adipocyte differentiation and obesity in mice. Chemico-Biological Interactions 2019298 24-34. (https://doi.org/10.1016/j.cbi.2018.10.021)

109 Kadawathagedara M, Tong ACH, Heude B, Forhan A, Charles MA, Sirot V, Botton J \& The Eden Mother-Child Cohort Study Group. Dietary acrylamide intake during pregnancy and anthropometry at birth in the French Eden mother-child cohort study. Environmental Research 2016149 189-196. (https://doi.org/10.1016/j. envres.2016.05.019)

110 Kadawathagedara M, Botton J de Lauzon-Guillain B, Meltzer HM, Alexander J, Brantsaeter AL, Haugen M \& Papadopoulou E. Dietary acrylamide intake during pregnancy and postnatal growth and obesity: Results from the Norwegian Mother and Child Cohort Study (MoBa). Environment International. 2018113 325-334.

111 Huang M, Zhuang P, Jiao J, Wang J \& Zhang Y. Association of acrylamide hemoglobin biomarkers with obesity, abdominal obesity and overweight in general US population: NHANES 2003-2006. Science of the Total Environment 2018 631-632 589-596. (https://doi. org/10.1016/j.scitotenv.2018.02.338)

112 Chu PL, Lin LY, Chen PC, Su TC \& Lin CY. Negative association between acrylamide exposure and body composition in adults: NHANES, 2003-2004. Nutrition \& Diabetes 20177 e246. (https://doi. org/10.1038/nutd.2016.48)

113 Chassaing B, Koren O, Goodrich JK, Poole AC, Srinivasan S, Ley RE \& Gewirtz AT. Dietary emulsifiers impact the mouse gut microbiota promoting colitis and metabolic syndrome. Nature 2015519 92-96. (https://doi.org/10.1038/nature14232)

114 Temkin AM, Bowers RR, Magaletta ME, Holshouser S, Maggi A, Ciana P, Guillette LJ, Bowden JA, Kucklick JR, Baatz JE, et al. Effects of crude oil/dispersant mixture and dispersant components on

This work is licensed under a Creative Commons Attribution-NonCommercial-NoDerivatives 4.0 Internationab ficense.ifica . com at $04 / 26 / 2023 \quad 10: 46: 40 \mathrm{AM}$ 
PPARgamma activity in vitro and in vivo: identification of dioctyl sodium sulfosuccinate (DOSS; CAS \#577-11-7) as a probable obesogen. Environmental Health Perspectives 2016124 112-119. (https://doi.org/10.1289/ehp.1409672)

115 Temkin AM, Bowers RR, Ulmer CZ, Penta K, Bowden JA, Nyland J, Baatz JE \& Spyropoulos DD. Increased adiposity, inflammation, metabolic disruption and dyslipidemia in adult male offspring of DOSS treated C57BL/6 dams. Scientific Reports 20199 1530. (https:// doi.org/10.1038/s41598-018-38383-9)

116 Gray JL, Kanagy LK, Furlong ET, Kanagy CJ, McCoy JW, Mason A \& Lauenstein G. Presence of the Corexit component dioctyl sodium sulfosuccinate in Gulf of Mexico waters after the 2010 Deepwater Horizon oil spill. Chemosphere 201495 124-130. (https://doi. org/10.1016/j.chemosphere.2013.08.049)

117 Bowers RR, Temkin AM, Guillette LJ, Baatz JE \& Spyropoulos DD. The commonly used nonionic surfactant Span 80 has RXRalpha transactivation activity, which likely increases the obesogenic potential of oil dispersants and food emulsifiers. General and Comparative Endocrinology 2016238 61-68. (https://doi. org/10.1016/j.ygcen.2016.04.029)

118 Sun Z, Yang X, Liu QS, Li C, Zhou Q, Fiedler H, Liao C, Zhang J $\&$ Jiang G. Butylated hydroxyanisole isomers induce distinct adipogenesis in 3T3-L1 cells. Journal of Hazardous Materials 2019379 120794. (https://doi.org/10.1016/j.jhazmat.2019.120794)

119 Sun Z, Tang Z, Yang X, Liu QS, Liang Y, Fiedler H, Zhang J, Zhou Q \& Jiang G. Perturbation of 3-tert-butyl-4-hydroxyanisole in adipogenesis of male mice with normal and high fat diets. Science of the Total Environment 2020703 135608. (https://doi.org/10.1016/j. scitotenv.2019.135608)

120 Imbernon M, Beiroa D, Vázquez MJ, Morgan DA, Veyrat-Durebex C, Porteiro B, Díaz-Arteaga A, Senra A, Busquets S, Velásquez DA, et al. Central melanin-concentrating hormone influences liver and adipose metabolism via specific hypothalamic nuclei and efferent autonomic/JNK1 pathways. Gastroenterology 2013144 636-649.e6. (https://doi.org/10.1053/j.gastro.2012.10.051)

121 Martin JM, Miranda RA, Barella LF, Palma-Rigo K, Alves VS, Fabricio GS, Pavanello A, Franco CC, Ribeiro TA, Visentainer JV, et al. Maternal Diet Supplementation with n-6/n-3 Essential Fatty Acids in a 1.2:1.0 Ratio Attenuates Metabolic Dysfunction in MSGInduced Obese Mice. International Journal of Endocrinology 20162016 9242319. (https://doi.org/10.1155/2016/9242319)

122 Jin YJ, Cao PJ, Bian WH, Li ME, Zhou R, Zhang LY \& Yang MZ. BDNF levels in adipose tissue and hypothalamus were reduced in mice with MSG-induced obesity. Nutritional Neuroscience 201518 376-382. (https://doi.org/10.1179/1476830515Y.0000000039)

123 Yulyaningsih E, Rudenko IA, Valdearcos M, Dahlén E, Vagena E, Chan A, Alvarez-Buylla A, Vaisse C, Koliwad SK \& Xu AW. Acute lesioning and rapid repair of hypothalamic neurons outside the blood-brain barrier. Cell Reports 201719 2257-2271. (https://doi. org/10.1016/j.celrep.2017.05.060)

124 Nagata M, Suzuki W, Iizuka S, Tabuchi M, Maruyama H, Takeda S, Aburada M \& Miyamoto K. Type 2 diabetes mellitus in obese mouse model induced by monosodium glutamate. Experimental Animals 200655 109-115. (https://doi.org/10.1538/expanim.55.109)

125 Shannon M, Green B, Willars G, Wilson J, Matthews N, Lamb J, Gillespie A \& Connolly L. The endocrine disrupting potential of monosodium glutamate (MSG) on secretion of the glucagon-like peptide-1 (GLP-1) gut hormone and GLP-1 receptor interaction. Toxicology Letters 2017265 97-105. (https://doi.org/10.1016/j. toxlet.2016.11.015)

126 Shannon M, Wilson J, Xie Y \& Connolly L. In vitro bioassay investigations of suspected obesogen monosodium glutamate at the level of nuclear receptor binding and steroidogenesis. Toxicology Letters 2019301 11-16. (https://doi.org/10.1016/j. toxlet.2018.10.021)
127 Acir IH \& Guenther K. Endocrine-disrupting metabolites of alkylphenol ethoxylates - A critical review of analytical methods, environmental occurrences, toxicity, and regulation. Science of the Total Environment 2018635 1530-1546. (https://doi.org/10.1016/j. scitotenv.2018.04.079)

128 Masuno H, Okamoto S, Iwanami J, Honda K, Shiosaka T, Kidani T, Sakayama K \& Yamamoto H. Effect of 4-nonylphenol on cell proliferation and adipocyte formation in cultures of fully differentiated 3T3-L1 cells. Toxicological Sciences 200375 314-320. (https://doi.org/10.1093/toxsci/kfg203)

129 Chang LL, Wun W-SA \& Wang PS. In utero and neonate exposure to nonylphenol develops hyperadrenalism and metabolic syndrome later in life. I. First generation rats (F1). Toxicology 2012301 40-49. (https://doi.org/10.1016/j.tox.2012.06.017)

130 Laws SC, Carey SA, Ferrell JM, Bodman GJ \& Cooper RL. Estrogenic activity of octylphenol, nonylphenol, bisphenol A and methoxychlor in rats. Toxicological Sciences 200054 154-167. (https://doi.org/10.1093/toxsci/54.1.154)

131 Mao Z, Zheng XF, Zhang YQ, Tao XX, Li Y \& Wang W. Occurrence and biodegradation of nonylphenol in the environment. International Journal of Molecular Sciences 201213 491-505. (https:// doi.org/10.3390/ijms13010491)

132 Vitali M, Ensabella F, Stella D \& Guidotti M. Nonylphenols in freshwaters of the hydrologic system of an Italian district: association with human activities and evaluation of human exposure. Chemosphere 200457 1637-1647. (https://doi.org/10.1016/j. chemosphere.2004.06.029)

133 Hou JW, Lin CL, Tsai YA, Chang CH, Liao KW, Yu CJ, Yang W, Lee MJ, Huang PC, Sun CW, et al. The effects of phthalate and nonylphenol exposure on body size and secondary sexual characteristics during puberty. International Journal of Hygiene and Environmental Health 2015218 603-615. (https://doi.org/10.1016/j. ijheh.2015.06.004)

134 Golden R, Gandy J \& Vollmer G. A review of the endocrine activity of parabens and implications for potential risks to human health. Critical Reviews in Toxicology 200535 435-458. (https://doi org/10.1080/10408440490920104)

135 Hu P, Chen X, Whitener RJ, Boder ET, Jones JO, Porollo A, Chen J \& Zhao L. Effects of parabens on adipocyte differentiation. Toxicological Sciences 2013131 56-70. (https://doi.org/10.1093/toxsci/kfs262)

136 Hu P, Overby H, Heal E, Wang S, Chen J, Shen CL \& Zhao L. Methylparaben and butylparaben alter multipotent mesenchymal stem cell fates towards adipocyte lineage. Toxicology and Applied Pharmacology 2017329 48-57. (https://doi.org/10.1016/j. taap.2017.05.019)

137 Kang HS, Kyung MS, Ko A, Park JH, Hwang MS, Kwon JE, Suh JH, Lee HS, Moon GI, Hong JH, et al. Urinary concentrations of parabens and their association with demographic factors: a population-based cross-sectional study. Environmental Research 2016146 245-251. (https://doi.org/10.1016/j.envres.2015.12.032)

138 Xue J, Wu Q, Sakthivel S, Pavithran PV, Vasukutty JR \& Kannan K. Urinary levels of endocrine-disrupting chemicals, including bisphenols, bisphenol A diglycidyl ethers, benzophenones, parabens, and triclosan in obese and non-obese Indian children. Environmental Research 2015137 120-128. (https://doi.org/10.1016/j. envres.2014.12.007)

139 Deierlein AL, Wolff MS, Pajak A, Pinney SM, Windham GC, Galvez MP, Rybak M, Calafat AM, Kushi LH, Biro FM, et al. Phenol concentrations During childhood and subsequent measures of adiposity Among young girls. American Journal of Epidemiology 2017 186 581-592. (https://doi.org/10.1093/aje/kwx136)

140 Guo J, Wu C, Lu D, Jiang S, Liang W, Chang X, Xu H, Wang G \& Zhou Z. Urinary paraben concentrations and their associations with anthropometric measures of children aged 3 years. Environmental Pollution 2017222 307-314 (Barking, Essex 1987). https://ec.bioscientifica.com

https://doi.org/10.1530/EC-20-0578
(C) 2021 The authors Published by Bioscientifica Ltd
This work is licensed under a Creative Commons Attribution-NonCommercial-NoDerivatives 4.0 Internationab ficense.ifica . com at 04/26/2023 10:46:40AM 
141 Leppert B, Strunz S, Seiwert B, Schlittenbauer L, Schlichting R, Pfeiffer C, Röder S, Bauer M, Borte M, Stangl GI, et al. Maternal paraben exposure triggers childhood overweight development. Nature Communications 202011 561. (https://doi.org/10.1038/ s41467-019-14202-1)

142 La Merrill M, Karey E, Moshier E, Lindtner C, La Frano MR, Newman JW \& Buettner C. Perinatal exposure of mice to the pesticide DDT impairs energy expenditure and metabolism in adult female offspring. PLOS ONE 20149 e103337. (https://doi. org/10.1371/journal.pone.0103337)

143 Warner M, Ye M, Harley K, Kogut K, Bradman A \& Eskenazi B. Prenatal DDT exposure and child adiposity at age 12: the CHAMACOS study. Environmental Research 2017159 606-612. (https://doi.org/10.1016/j.envres.2017.08.050)

144 La Merrill MA, Krigbaum NY, Cirillo PM \& Cohn BA. Association between maternal exposure to the pesticide dichlorodiphenyltrichloroethane (DDT) and risk of obesity in middle age. International Journal of Obesity 202044 1723-1732. (https://doi. org/10.1038/s41366-020-0586-7)

145 Valvi D, Mendez MA, Martinez D, Grimalt JO, Torrent M, Sunyer J \& Vrijheid M. Prenatal concentrations of polychlorinated biphenyls, DDE, and DDT and overweight in children: a prospective birth cohort study. Environmental Health Perspectives 2012120 451-457. (https://doi.org/10.1289/ehp.1103862)

146 Park Y, Kim Y, Kim J, Yoon KS, Clark J, Lee J \& Park Y. Imidacloprid, a neonicotinoid insecticide, potentiates adipogenesis in 3T3-L1 adipocytes. Journal of Agricultural and Food Chemistry 201361 255-259. (https://doi.org/10.1021/jf3039814)

147 Sun Q, Xiao X, Kim Y, Kim D, Yoon KS, Clark JM \& Park Y. Imidacloprid promotes high fat diet-induced adiposity and insulin resistance in male C57BL/6J mice. Journal of Agricultural and Food Chemistry 201664 9293-9306. (https://doi.org/10.1021/acs. jafc.6b04322)

148 Biserni M, Mesnage R, Ferro R, Wozniak E, Xenakis T, Mein CA \& Antoniou MN. Quizalofop-p-ethyl induces adipogenesis in 3T3-L1 adipocytes. Toxicological Sciences 2019170 452-461. (https://doi. org/10.1093/toxsci/kfz097)

149 Liu B, Lehmler HJ, Sun Y, Xu G, Liu Y, Zong G, Sun Q, Hu FB, Wallace RB \& Bao W. Bisphenol A substitutes and obesity in US adults: analysis of a population-based, cross-sectional study. Planetary Health 20171 e114-e122. (https://doi.org/10.1016/S25425196(17)30049-9)

150 Andújar N, Gálvez-Ontiveros Y, Zafra-Gómez A, Rodrigo L, ÁlvarezCubero MJ, Aguilera M, Monteagudo C \& Rivas AA. Bisphenol A analogues in food and their hormonal and obesogenic effects: a review. Nutrients 2019 11. (https://doi.org/10.3390/nu11092136)

151 Catanese MC, Vandenberg LN. Bisphenol S (BPS) alters maternal behavior and brain in mice exposed During pregnancy/lactation and their daughters. Endocrinology 2017158 516-530. (https://doi. org/10.1210/en.2016-1723)

152 Hill CE, Sapouckey SA, Suvorov A \& Vandenberg LN. Developmental exposures to bisphenol S, a BPA replacement, alter estrogenresponsiveness of the female reproductive tract: a pilot study. Cogent Medicine 2017 4. (https://doi.org/10.1080/2331205X.2017.1317690)

153 Pelch K, Wignall JA, Goldstone AE, Ross PK, Blain RB, Shapiro AJ, Holmgren SD, Hsieh JH, Svoboda D, Auerbach SS, et al. A scoping review of the health and toxicological activity of bisphenol A (BPA) structural analogues and functional alternatives. Toxicology 2019424 152235. (https://doi.org/10.1016/j.tox.2019.06.006)

154 Riu A, Grimaldi M, le Maire A, Bey G, Phillips K, Boulahtouf A, Perdu E, Zalko D, Bourguet W \& Balaguer P. Peroxisome proliferatoractivated receptor gamma is a target for halogenated analogs of bisphenol A. Environmental Health Perspectives 2011119 1227-1232. (https://doi.org/10.1289/ehp.1003328)

155 Ahmed S \& Atlas E. Bisphenol S- and bisphenol A-induced adipogenesis of murine preadipocytes occurs through direct peroxisome proliferator-activated receptor gamma activation. International Journal of Obesity 201640 1566-1573. (https://doi. org/10.1038/ijo.2016.95)

156 Ivry Del Moral L, Le Corre L, Poirier H, Niot I, Truntzer T, Merlin JF, Rouimi P, Besnard P, Rahmani R \& Chagnon MC. Obesogen effects after perinatal exposure of 4,4'-sulfonyldiphenol (bisphenol S) in C57BL/6 mice. Toxicology 2016 357-358 11-20. (https://doi. org/10.1016/j.tox.2016.05.023)

167 Jacobson MH, Woodward M, Bao W, Liu B \& Trasande L. Urinary bisphenols and obesity prevalence Among U.S. Children and adolescents. Journal of the Endocrine Society 20193 1715-1726. (https://doi.org/10.1210/js.2019-00201)

158 Muncke J. Endocrine disrupting chemicals and other substances of concern in food contact materials: an updated review of exposure, effect and risk assessment. Journal of Steroid Biochemistry and Molecular Biology 2011127 118-127. (https://doi.org/10.1016/j. jsbmb.2010.10.004)

159 Fristachi A, Xu Y, Rice G, Impellitteri CA, Carlson-Lynch H \& Little JC. Using probabilistic modeling to evaluate human exposure to organotin in drinking water transported by polyvinyl chloride pipe. Risk Analysis 200929 1615-1628. (https://doi.org/10.1111/ j.1539-6924.2009.01307.x)

160 Milton FA, Lacerda MG, Sinoti SBP, Mesquita PG, Prakasan D, Coelho MS, de Lima CL, Martini AG, Pazzine GT, Borin MF, et al. Dibutyltin compounds effects on PPARgamma/RXRalpha activity, adipogenesis, and inflammation in mammalians cells. Frontiers in Pharmacology 20178 507. (https://doi.org/10.3389/ fphar.2017.00507)

161 Chamorro-García R, Shoucri BM, Willner S, Käch H, Janesick A \& Blumberg B. Effects of perinatal exposure to dibutyltin chloride on fat and glucose metabolism in mice, and molecular mechanisms, in vitro. Environmental Health Perspectives 2018126 057006. (https:// doi.org/10.1289/EHP3030)

162 Grun F \& Blumberg B. Environmental obesogens: organotins and endocrine disruption via nuclear receptor signaling. Endocrinology 2006 147(Supplement) S50-S55. (https://doi.org/10.1210/en.20051129)

163 Guo H, Yan H, Cheng D, Wei X, Kou R \& Si J. Tributyltin exposure induces gut microbiome dysbiosis with increased body weight gain and dyslipidemia in mice. Environmental Toxicology and Pharmacology 201860 202-208. (https://doi.org/10.1016/j.etap.2018.04.020)

164 Wang D, Yan S, Yan J, Teng M, Meng Z, Li R, Zhou Z \& Zhu W. Effects of triphenyl phosphate exposure during fetal development on obesity and metabolic dysfunctions in adult mice: impaired lipid metabolism and intestinal dysbiosis. Environmental Pollution 2019 246 630-638. (https://doi.org/10.1016/j.envpol.2018.12.053)

165 Attina TM, Hauser R, Sathyanarayana S, Hunt PA, Bourguignon JP, Myers JP, DiGangi J, Zoeller RT \& Trasande L. Exposure to endocrinedisrupting chemicals in the USA: a population-based disease burden and cost analysis. Lancet. Diabetes \& Endocrinology 20164 996-1003. (https://doi.org/10.1016/S2213-8587(16)30275-3)

166 Legler J, Fletcher T, Govarts E, Porta M, Blumberg B, Heindel JJ \& Trasande L. Obesity, diabetes, and associated costs of exposure to endocrine-disrupting chemicals in the European Union. Journal of Clinical Endocrinology and Metabolism 2015100 1278-1288. (https:// doi.org/10.1210/jc.2014-4326)

167 Newbold RR, Padilla-Banks E, Snyder RJ \& Jefferson WN. Developmental exposure to estrogenic compounds and obesity. Birth Defects Research. Part A, Clinical and Molecular Teratology 200573 478-480. (https://doi.org/10.1002/bdra.20147)

168 Hales CM, Carroll MD, Fryar CD \& Ogden CL. Prevalence of obesity among adults and youth: United States, 2015-2016. NCHS Data Brief 2017 (288) 1-8.

169 Kuznetsova T, Wang SY, Rao NA, Mandoli A, Martens JHA, Rother N, Aartse A, Groh L, Janssen-Megens EM, Li G, et al. Glucocorticoid receptor and nuclear factor kappa-B affect three-dimensional 
chromatin organization. Genome Biology 201516 264. (https://doi. org/10.1186/s13059-015-0832-9)

170 Trotter KW \& Archer TK. Nuclear receptors and chromatin remodeling machinery. Molecular and Cellular Endocrinology 2007 265-266 162-167. (https://doi.org/10.1016/j.mce.2006.12.015)

171 Jacobsen PR, Axelstad M, Boberg J, Isling LK, Christiansen S, Mandrup KR, Berthelsen LO, Vinggaard AM \& Hass U. Persistent developmental toxicity in rat offspring after low dose exposure to a mixture of endocrine disrupting pesticides. Reproductive Toxicology 201234 237-250. (https://doi.org/10.1016/j.reprotox.2012.05.099)

172 Kjærstad MB, Taxvig C, Andersen HR \& Nellemann C. Mixture effects of endocrine disrupting compounds in vitro. International Journal of Andrology 201033 425-433. (https://doi.org/10.1111/j.13652605.2009.01034.x)

173 Kortenkamp A. Low dose mixture effects of endocrine disrupters: implications for risk assessment and epidemiology. International Journal of Andrology 200831 233-240. (https://doi.org/10.1111/ j.1365-2605.2007.00862.x)

174 Le Magueresse-Battistoni B, Vidal H \& Naville D. Environmental pollutants and metabolic disorders: the multi-exposure scenario of life. Frontiers in Endocrinology 20189 582. (https://doi.org/10.3389/ fendo.2018.00582)

175 176. Delfosse V, Grimaldi M, le Maire A, Bourguet W \& Balaguer P. Nuclear receptor profiling of bisphenol-A and its halogenated analogues. Vitamins and Hormones 201494 229-251. (https://doi. org/10.1016/B978-0-12-800095-3.00009-2)

176 Vom Saal FS, Nagel SC, Coe BL, Angle BM \& Taylor JA. The estrogenic endocrine disrupting chemical bisphenol A (BPA) and obesity. Molecular \& Cellular Endocrinology 2012354 74-84. (https://doi. org/10.1016/j.mce.2012.01.001)

177 Kim J, Sun Q, Yue Y, Yoon KS, Whang KY, Marshall Clark J \& Park Y. 4,4'-Dichlorodiphenyltrichloroethane (DDT) and 4,4'-dichlorodiphenyldichloroethylene (DDE) promote adipogenesis in 3T3-L1 adipocyte cell culture. Pesticide Biochemistry \& Physiology 2016131 40-45. (https://doi.org/10.1016/j.pestbp.2016.01.005)

178 Mangum LH, Howell GE, 3rd \& Chambers JE. Exposure to p,p'-DDE enhances differentiation of 3T3-L1 preadipocytes in a model of suboptimal differentiation. Toxicology Letters 2015238 65-71. (https:// doi.org/10.1016/j.toxlet.2015.07.009)

179 Stahlhut RW, van Wijngaarden E, Dye TD, Cook S \& Swan SH. Concentrations of urinary phthalate metabolites are associated with increased waist circumference and insulin resistance in adult U.S. males. Environmental Health Perspectives 2007115 876-882. (https:// doi.org/10.1289/ehp.9882)
180 Hatch EE, Nelson JW, Qureshi MM, Weinberg J, Moore LL, Singer M \& Webster TF. Association of urinary phthalate metabolite concentrations with body mass index and waist circumference: a cross-sectional study of NHANES data, 1999-2002. Environmental Health 20087 27. (https://doi.org/10.1186/1476-069X-7-27)

181 Hao C, Cheng X, Guo J, Xia H \& Ma X. Perinatal exposure to diethylhexyl-phthalate induces obesity in mice. Frontiers in Bioscience (Elite Edition) 20135 725-733. (https://doi.org/10.2741/e653)

182 Choi J, Eom J, Kim J, Lee S \& Kim Y. Association between some endocrine-disrupting chemicals and childhood obesity in biological samples of young girls: a cross-sectional study. Environmental Toxicology \& Pharmacology 201438 51-57. (https://doi.org/10.1016/j. etap.2014.04.004)

183 Schmidt JS, Schaedlich K, Fiandanese N, Pocar P \& Fischer B. Effects of di(2-ethylhexyl) phthalate (DEHP) on female fertility and adipogenesis in C3H/N mice. Environmental Health Perspectives 2012 120 1123-1129. (https://doi.org/10.1289/ehp.1104016)

184 Feige JN, Gelman L, Rossi D, Zoete V, Metivier R, Tudor C, Anghel SI, Grosdidier A, Lathion C, Engelborghs Y, et al. The endocrine disruptor monoethyl-hexyl-phthalate is a selective peroxisome proliferator-activated receptor gamma modulator that promotes adipogenesis. Journal of Biological Chemistry 2007282 19152-19166. (https://doi.org/10.1074/jbc.M702724200)

185 Li X, Pham HT, Janesick AS \& Blumberg B. Triflumizole is an obesogen in mice that acts through peroxisome proliferator activated receptor gamma (PPARgamma). Environmental Health Perspectives 2012120 1720-1726. (https://doi.org/10.1289/ehp.1205383)

186 Wang ML, Lin SH, Hou YY \& Chen YH. Alpha-naphthoflavone increases lipid accumulation in mature adipocytes and enhances adipocyte-stimulated endothelial tube formation. Nutrients $2015 \mathbf{7}$ 3166-3183. (https://doi.org/10.3390/nu7053166)

187 Chamorro-Garcia R, Kirchner S, Li X, Janesick A, Casey SC, Chow C \& Blumberg B. Bisphenol A diglycidyl ether induces adipogenic differentiation of multipotent stromal stem cells through a peroxisome proliferator-activated receptor gamma-independent mechanism. Environmental Health Perspectives 2012120 984-989. (https://doi.org/10.1289/ehp.1205063)

188 Wang Y, Zhao S \& Rafael S (CA) Report 2010.

189 Smith A, Yu X \& Yin L. Diazinon exposure activated transcriptional factors CCAAT-enhancer-binding proteins alpha (C/EBPalpha) and peroxisome proliferator-activated receptor gamma (PPARgamma) and induced adipogenesis in 3T3-L1 preadipocytes. Pesticide Biochemistry \& Physiology 2018150 48-58. (https://doi.org/10.1016/j. pestbp.2018.07.003)

Received in final form 7 December 2020

Accepted 6 January 2021

Accepted Manuscript published online 8 January 2021 https://ec.bioscientifica.com https://doi.org/10.1530/EC-20-0578 (c) 2021 The authors Published by Bioscientifica Ltd
This work is licensed under a Creative Commons Attribution-NonCommercial-NoDerivatives 4.0 International License.ifica .com at $04 / 26 / 2023$ 10:46:40AM 